The Canadian Mineralogist

Vol. 42, pp. 1465-1481 (2004)

\title{
HYDROTHERMAL As-Bi MINERALIZATION IN THE NAKDONG DEPOSITS, SOUTH KOREA: INSIGHT FROM FLUID INCLUSIONS AND STABLE ISOTOPES
}

\author{
DongboK SHIN $\mathbb{I}$, HeE-In PARK AND INSUNG LEE $\$$ \\ School of Earth and Environmental Sciences, Seoul National University, Shilim-dong San56-1, \\ Kwanak-gu, Seoul 151-742, South Korea \\ KWANG-SIK LEE \\ Isotope Research Team, Korea Basic Science Institute, Daejeon 305-333, South Korea \\ JEONG HWANG \\ Department of Geosystem Engineering, Daejeon University, Daejeon 300-716, South Korea
}

\begin{abstract}
At the Nakdong As-Bi deposits, South Korea, Cambro-Ordovician sedimentary sequences are cut by numerous dykes of quartz monzodiorite and porphyritic granite. In the deposit, stage I involves arsenic mineralization, chiefly associated with arsenopyrite, pyrite, sphalerite and chalcopyrite, whereas bismuth mineralization characterizes stage II, with the coprecipitation of pyrrhotite, chalcopyrite, galena, bismuth, bismuthinite, cosalite, matildite, schirmerite, $\mathrm{Au}-\mathrm{Ag}$ alloy, and argentite. The mineralization was initiated with the introduction of heterogeneous fluids of high salinity, presumably owing to the prominence of $\mathrm{Ca}, \mathrm{Mg}, \mathrm{Na}$ and $\mathrm{K}$. At stage II, fluid immiscibility, which led to bismuth mineralization, produced (halite \pm sylvite)-bearing highsalinity fluids of 27.6 to $49.3 \mathrm{wt} . \% \mathrm{NaCl}$ equivalents, as well as low-salinity vapor-rich fluids. The homogenization temperatures of mineralizing fluids decreased only slightly from stage I, $283-416^{\circ} \mathrm{C}$, to stage II, $222-395^{\circ} \mathrm{C}$. A decrease in ${ }^{18} \mathrm{O}$ as well as ${ }^{13} \mathrm{C}$ in going from calcite in fresh limestone $\left(\delta^{18} \mathrm{O}\right.$ in the range +17.5 to $+22.4 \% o, \delta^{13} \mathrm{C}$ in the range +2.3 to $+4.4 \%$ ) to silicified limestone $\left(\delta^{18} \mathrm{O}\right.$ in the range +13.3 to $+18.3 \% o, \delta^{13} \mathrm{C}$ in the range -2.5 to $+1.3 \%$ ) were promoted not only by Rayleigh volatilization, but also by fluid-rock interaction, with the influx of magmatic fluids into carbonate rocks during the mineralization process. The fluid-rock interaction contributed to the $\mathrm{CO}_{2}$ and $\mathrm{CH}_{4}$ components in type-III fluids and also to the Ca-enrichment in type-I fluid inclusions. The prevailing species of sulfur in the mineralizing fluids is estimated to have been $\mathrm{H}_{2} \mathrm{~S}$. The $\delta^{34} \mathrm{~S}_{\mathrm{H} 2 \mathrm{~S}}$ values obtained from the sulfide minerals increased from stage I, +3.2 to $+4.4 \%$, to stage II, +4.1 to $+4.8 \%$, values typical of magmatic sulfur, and the temperatures of homogenization of fluid inclusions increased as well. The decrease of sulfur fugacities, from $10^{-9.1}-10^{-6.4} \mathrm{~atm}$ at stage I to $10^{-15.7}-10^{-9.2}$ atm at stage II, through sulfide precipitation and $\mathrm{H}_{2} \mathrm{~S}$ loss, induced the destabilization of bisulfide complexes and characterized the change of mineral stabilities from arsenopyrite - pyrite - sphalerite to bismuthinite - native bismuth assemblages.
\end{abstract}

Keywords: Nakdong As-Bi deposits, fluid inclusions, heterogeneous fluids, stable isotopes, fluid-rock interaction, isotopic depletion, sulfur fugacity, South Korea.

\section{SOMMAIRE}

Dans le gisement à As-Bi de Nakdong, en Corée du Sud, des séquences sédimentaires d'âge cambro-ordovicien sont recoupées par de nombreux filons de monzodiorite quartzifère et de granite porphyritique. Dans ce gisement, le premier stade de minéralisation a impliqué la déposition d'arsenic, en association avec arsénopyrite, pyrite, sphalérite et chalcopyrite, tandis qu'une minéralisation en bismuth a caractérisé le deuxième stade, avec coprécipitation de pyrrhotite, chalcopyrite, galène, bismuth, bismuthinite, cosalite, matildite, schirmerite, alliage $\mathrm{Au}-\mathrm{Ag}$, et argentite. La minéralisation fut initiée par l'introduction de fluides hétérogènes à salinité élevée, probablement à cause de l'importance de $\mathrm{Ca}, \mathrm{Mg}, \mathrm{Na}$ et $\mathrm{K}$. Au stade II, une immiscibilité dans la phase fluide, qui a provoqué la minéralisation en bismuth, a produit des inclusions fluides à halite \pm sylvite, et donc à salinité élevée, entre 27.6 et $49.3 \%$ par poids de $\mathrm{NaCl}$, ainsi qu'une fraction vapeur à salinité réduite. La température d'homogénéisation des fluides minéralisateurs n'a diminué que légèrement du stade I, $283-416^{\circ} \mathrm{C}$, au stade II, $222-395^{\circ} \mathrm{C}$. Une diminution de la

$\S \quad$ E-mail address: insung @ snu.ac.kr

Il Present address: Isotope Research Team, Korea Basic Science Institute, 52 Eoeun-dong, Yusung-gu, Daejeon 305-333, South Korea. 
proportion de ${ }^{18} \mathrm{O}$ et de ${ }^{13} \mathrm{C}$ entre la calcite du calcaire frais $\left(\delta^{18} \mathrm{O}\right.$ entre +17.5 et $+22.4 \%$ o, $\delta^{13} \mathrm{C}$ entre +2.3 et $\left.+4.4 \% o\right)$ et du calcaire silicifié $\left(\delta^{18} \mathrm{O}\right.$ entre +13.3 et $+18.3 \%$ o, $\delta^{13} \mathrm{C}$ entre -2.5 et $+1.3 \%$ ) a été causée non seulement par une volatilisation selon la loi de Rayleigh, mais aussi par interaction des roches avec une phase fluide d'origine magmatique dans les roches carbonatées au cours de la minéralisation. L'interaction des fluides et des roches a contribué les composantes $\mathrm{CO}_{2}$ et $\mathrm{CH}_{4}$ aux fluides de type III et explique aussi l'enrichissement en Ca des inclusions de type I. L'espèce principale porteuse de soufre dans la phase fluide aurait été $\mathrm{H}_{2} \mathrm{~S}$. Les valeurs de $\delta^{34} \mathrm{~S}_{\mathrm{H} 2 \mathrm{~S}}$ des minéraux sulfurés augmentent du stade I, +3.2 à $+4.4 \%$, au stade II, +4.1 à $+4.8 \%$, valeurs typiques du soufre magmatique, et les températures d'homogénéisation des inclusions fluides a augmenté de même. La diminution de la fugacité du soufre, de $10^{-9.1}-10^{-6.4} \mathrm{~atm}$ au stade $\mathrm{I}$ à $10^{-15.7}-10^{-9.2} \mathrm{~atm}$ au stade II, due à la précipitation des sulfures et à la perte en $\mathrm{H}_{2} \mathrm{~S}$, a mené à la déstabilisation des complexes bisulfurés et au changement des champs de stabilité des minéraux, de arsénopyrite - pyrite - sphalérite à l'assemblage bismuthinite - bismuth natif.

(Traduit par la Rédaction)

Mots-clés: gisements à As-Bi de Nakdong, inclusions fluides, fluides hétérogènes, isotopes stables, interaction fluide-roche, appauvrissement isotopique, fugacité de soufre, Corée du Sud.

\section{INTRODUCTION}

Numerous hydrothermal deposits of gold, silver and other related metals, such as $\mathrm{Pb}, \mathrm{Zn}, \mathrm{Cu}, \mathrm{Sb}, \mathrm{Fe}, \mathrm{Mo}$, As and $\mathrm{Bi}$, are densely clustered around Cretaceous granitic plutons in the Taebaegsan region of South Korea (Park et al. 1988, Park \& Lee 1990, Hur \& Park 2000). One noteworthy igneous body in this region is the Jeongseon pluton, consisting of quartz monzodiorite, quartz monzonite and granite; several deposits are disposed around it, including the Shinjeongseon $\mathrm{Pb}-\mathrm{Zn}$ deposit and the Shinchi $\mathrm{Cu}$ deposit. Also, the Hamchang $\mathrm{Pb}-\mathrm{Zn}$ deposit is $1 \mathrm{~km}$ off to the east, and the Nakdong As-Bi deposit is $2 \mathrm{~km}$ to the south. These ore deposits show close temporal and spatial relationship to the granitic plutons, but each has a distinct assemblage of minerals.

Here, we are interested in the Nakdong deposit, one of the rare deposits of bismuth ore in South Korea. The deposit was initially exploited for arsenic. Then, with the discovery of bismuth, both elements were extensively sought during the mid-1980s. The Nakdong deposit contains in excess of 20,000 metric tonnes of sulfide ore (mined + estimated reserves) grading $26.6 \%$ As and 0.58\% Bi (KMPC 1974).

Our objectives in this study are: (1) to document the occurrence of As-Bi minerals, (2) to elucidate the characteristics of fluid evolution by constraining the physicochemical conditions of arsenic and bismuth mineralization based on the microthermometric analysis of fluid inclusions, sulfur isotope compositions and mineralogy of the ores, and (3) to shed light on the mechanism of oxygen and carbon isotopic depletions observed in the carbonate rocks around the deposit.

\section{Geological Setting}

The Ogcheon Metamorphic Belt (OMB) forms the boundary between two Precambrian blocks, Gyeonggi to the northwest and Ryeongnam to the southeast in South Korea (Fig. 1). The OMB has traditionally been divided into a southwestern metamorphic block and a northeastern non-metamorphic area, also referred to as the "Ogcheon zone" and the "Taebaegsan zone", respectively. The Taebaegsan and Ogcheon regions correspond to the early Paleozoic platform and rift domains, respectively (Cluzel et al. 1990). The Taebaegsan region is composed of a Precambrian basement with a Cambrian to mid-Silurian autochthonous and para-autochthonous cover, the Joseon Supergroup (Lee 1979). Cretaceous granitic bodies in this region occur in the form of small-scale stocks and dykes that consist of more than three phases. These granites are emplaced within or near the NS- to NNE-trending faults (Park \& Lee 1990, Hur \& Park 2000). Although these granites typically show mineralogical and chemical features of I-type granite and the calc-alkaline series, their initial ${ }^{87} \mathrm{Sr} /{ }^{86} \mathrm{Sr}$ and $\delta^{18} \mathrm{O}$ values are interpreted to reflect assimilation of ${ }^{18} \mathrm{O}$ - and ${ }^{87} \mathrm{Sr}$-enriched Precambrian metasedimentary rocks by a ${ }^{18} \mathrm{O}$ - and ${ }^{87} \mathrm{Sr}$-depleted upper-mantle-derived magma (Hur et al. 2000). The K$\mathrm{Ar}$ ages of the granites are 50 to $108 \mathrm{Ma}$, and those associated with the ore deposits ( $\mathrm{Au}, \mathrm{Ag}, \mathrm{Fe}, \mathrm{Pb}, \mathrm{Zn}$, $\mathrm{As}, \mathrm{Sb}$, and $\mathrm{Bi}$ ) are in the range 52-86 $\mathrm{Ma}$ (Park et al. 1988, Park \& Lee 1990, Hur \& Park 2000).

In the Nakdong area, rocks of the Cambro-Ordovician Joseon Supergroup from the Hwajeol Formation to the Jeongseon Limestone northwestwardly are intruded by Cretaceous igneous rocks (Fig. 1). The Maggol Formation, the local host-rock for the deposit, consists mainly of platy limestone locally interbedded with dolomite. Jeong (1995) proposed that the Jeongseon area has undergone four phases of deformation and metamorphism. North-south-trending mesoscale extensional fractures and strike-slip faults, active during the fourth stage of deformation in the early Cretaceous, reactivated the preceding faults, and seem to have contributed to the intrusion of the Jeongseon granitic rocks, including the north-south-trending dykes in the study area.

The Jeongseon granitic rocks are exposed as a stock with numerous associated dykes of north-south to $\mathrm{N} 10^{\circ} \mathrm{W}$ direction, extending to the western region of the Nakdong mining area. These dykes are $<100 \mathrm{~m}$ wide 


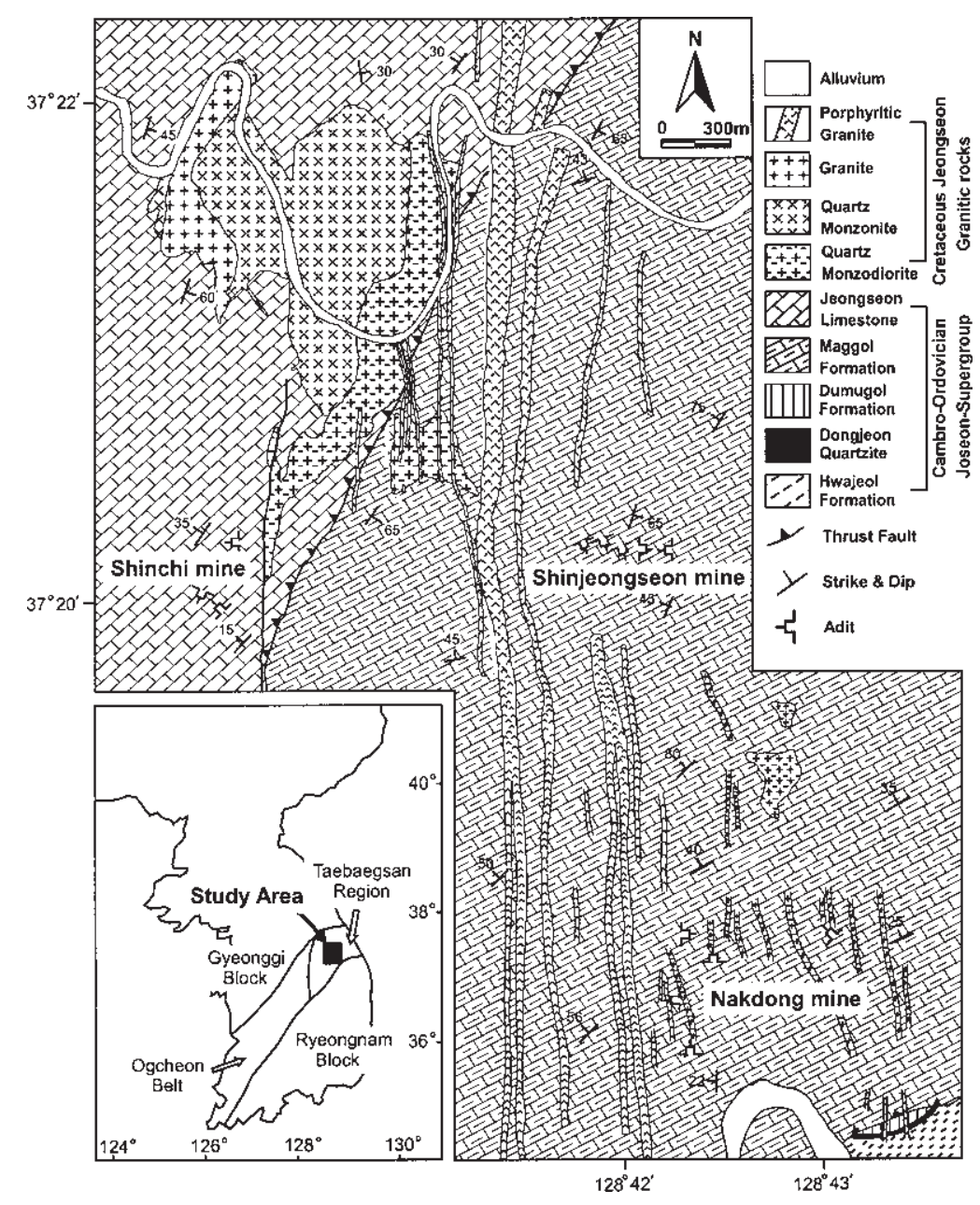

FIG. 1. Geological map of the Nakdong mine area and the Jeongseon pluton.

and $<8 \mathrm{~km}$ length. Their emplacement temperature and pressure, calculated using the hornblende geothermobarometer, are 611 to $645^{\circ} \mathrm{C}$ and $<1 \mathrm{kbar}$, respectively (Hur 1997). The dykes become darker in color and are more porphyritic toward the chilled margins. Plagioclase and quartz are the main constituents of the porphyries, with minor orthoclase and hornblende. The dark minerals become more common toward the margins. A second set of dyke rocks, of quartz monzodiorite composition, are oriented north-south to $\mathrm{N} 30^{\circ} \mathrm{W}$ and range from a few centimeters to several tens of meters in width in the eastern part of the Nakdong mining area. The major constituent minerals of these dykes are quartz, orthoclase, plagioclase, biotite, and hornblende, with accessory pyroxene, chlorite, titanite, epidote, and rutile.

\section{Analytical Methods}

The chemical composition of $\mathrm{Au}-\mathrm{Ag}$ alloy and the $\mathrm{FeS}$ content of sphalerite were obtained using a JXA 8900R electron-microprobe analyzer at Seoul National University. We used $\mathrm{Au}-\mathrm{Ag}$ alloy samples with different $\mathrm{Au}: \mathrm{Ag}$ ratios, natural chalcopyrite and sphalerite as standards. The analytical conditions were: accelerating voltage $20 \mathrm{kV}$ and beam current $15 \mathrm{nA}$. The $\mathrm{K}-\mathrm{Ar}$ age of white mica related to the hydrothermal alteration was measured using a MICROMASS 5400 at Korea Basic Science Institute.

A fluid-inclusion study was carried out to constrain the $\mathrm{P}-\mathrm{T}$ conditions during mineralization and to characterize the mineralizing fluids. Microthermometric 
measurements were performed on primary and pseudosecondary inclusions, classified using the criteria of Roedder (1984), in quartz and calcite from various stages. Measurements were made using a Fluid Inc. U.S.G.S.-type gas-flow heating-freezing stage at Seoul National University. Synthetic fluid-inclusions and melting-point standards from the Thomas Company were used for temperature calibration. Errors in measurement during the freezing and heating experiments were $\pm 0.2 \%$ and $\pm 1{ }^{\circ} \mathrm{C}$, respectively.

Stable isotope studies were conducted to reveal the origin of mineralizing fluids and genetic environment of the ore deposits. In this study, we measured sulfur isotope compositions of sulfide minerals, carbon isotope compositions of $\mathrm{CO}_{2}$ gas, and hydrogen isotope compositions of inclusion waters extracted from vein quartz, carbon and oxygen isotope compositions from fresh platy limestone, silicified limestone, and vein calcite using a VG Isotech PRISM II spectrometer at the Korea Basic Science Institute. For the oxygen isotope measurement of vein quartz, we used the method of Clayton \& Mayeda (1963) to produce $\mathrm{CO}_{2}$ gas. The gas fraction was analyzed on a Finnigan MAT252 mass spectrometer with a dual inlet at Indiana University. Sulfur isotope data are expressed relative to CDT, carbon isotope relative to $\mathrm{PDB}$, and oxygen and hydrogen isotope relative to SMOW. Analytical errors are $\pm 0.2 \%$ o for sulfur, $\pm 1.0 \%$ o for hydrogen, and $\pm 0.1 \%$ o for both carbon and oxygen.

\section{Ore Deposits and Ore Mineralogy}

About ten mine drifts were developed in the Nakdong mine, but only half of them were exploited for arsenic and bismuth. The arsenic orebodies are commonly 1 to $2 \mathrm{~m}$ in thickness, with either an irregular or lenticular shape. The ores formed by replacement of the platy Maggol limestone along bedding planes. The main body reaches 3 to $5 \mathrm{~m}$ in width and $200 \mathrm{~m}$ in length. Bismuth minerals are commonly found in quartz veins of $<10$ to $30 \mathrm{~cm}$ across that fill fracture zones developed in the Maggol limestone or at the contacts between the igneous bodies and limestone. The major bismuthbearing orebody is $5 \mathrm{~m}$ width and $40-50 \mathrm{~m}$ in length. Since most of the vein-type orebodies are strongly controlled by dyke rocks, they are naturally of north-south orientation. The $\mathrm{K}-\mathrm{Ar}$ age of the white mica formed by wallrock alteration was measured to be $69 \pm 3 \mathrm{Ma}$. Hur \& Park (2000) also reported that the K-Ar age of the biotite in quartz monzonite and whole-rock age of porphyritic granite from the Jeongseon granitic rocks are $105 \pm 2 \mathrm{Ma}$ and $74 \pm 2 \mathrm{Ma}$, respectively. According to these results, the As-Bi mineralization seems to be genetically related to the porphyritic granite of the Jeongseon pluton.

A paragenetic sequence for ore minerals was established from the ore mineralogy and replacement textures. We recognize three stages of mineralization
(Fig. 2). Mineralized veins of stage I commonly formed lenticular orebodies. Toward the upper portions of the vein body, an orebody tends to be divided into several smaller bodies. The veins are massive in appearance. The relative volumetric proportions of quartz to carbonates in the veins are generally more than 7:3, with traces of chlorite. At this stage, arsenopyrite, pyrite, sphalerite, and chalcopyrite were produced as massive orebodies. Arsenopyrite usually occurs as aggregates of euhedral or subhedral crystals ranging in size from 200 $\mu \mathrm{m}$ to a few millimeters. It coexists with pyrite and forms massive aggregates of variable grain-size. Arsenopyrite and pyrite are replaced by later-stage ore minerals such as pyrrhotite, chalcopyrite, native bismuth and galena (Fig. 3). The sphalerite contains blebs of chalcopyrite aligned parallel to the faces of the sphalerite crystals. Quartz, calcite, and chlorite constitute the gangue minerals.

The quartz veins of stage II generally show open vugs with quartz crystals and calcite. Gangue minerals mainly consist of quartz $(>80 \%)$, calcite, and small amounts of prismatic or acicular tremolite and tabular phlogopite. Ore minerals generally comprise less than 5 vol. $\%$ of the quartz vein. At this stage, pyrrhotite, chalcopyrite, galena, bismuth minerals, $\mathrm{Au}-\mathrm{Ag}$ alloy, and argentite were formed, as well as pyrite. They commonly replaced the stage-I arsenopyrite and pyrite. The pyrrhotite is strongly anisotropic and magnetic, and is partly altered to marcasite and has a bird's-eye texture.

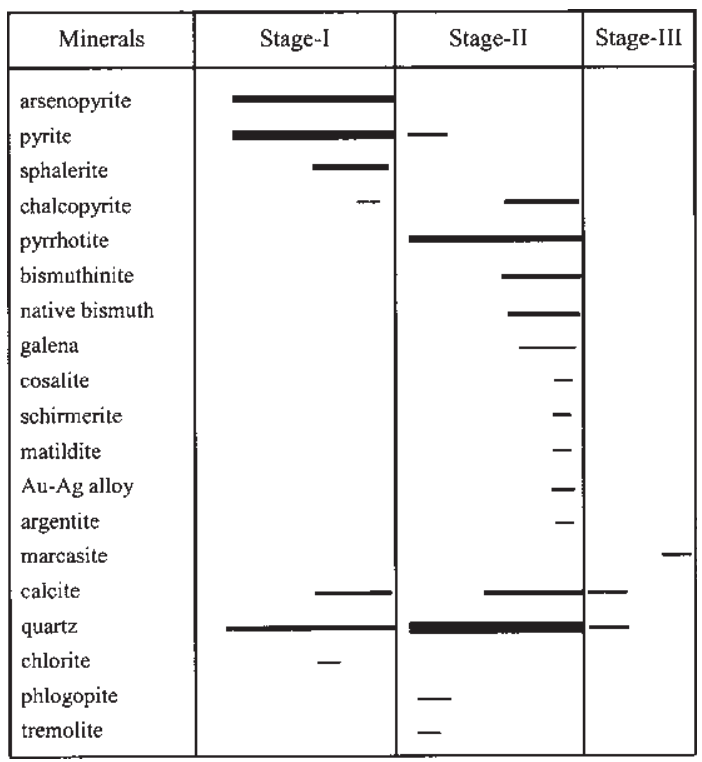

FIG. 2. Paragenetic sequence of ore and gangue minerals at the Nakdong deposits. Line thickness represents schematically the relative abundances of minerals. 
Chalcopyrite is closely associated with pyrrhotite, galena, and native bismuth. Lead-gray to tin-white bismuthinite has a metallic luster and weak lamellar twinning, and usually occurs as anhedral grains. Minerals containing $\mathrm{Pb}-\mathrm{Ag}-\mathrm{Bi}-\mathrm{S}$, such as cosalite and galena-matildite solid solutions, are also observed. $\mathrm{Au}-\mathrm{Ag}$ alloy, associated with native bismuth, infills cracks in pyrite; the grain size ranges from 30 to $80 \mu \mathrm{m}$ in general, but in some cases it attains $200 \mu \mathrm{m}$ (Fig. 3). The $\mathrm{Au}-\mathrm{Ag}$ alloy shows various colors, from pale yellow to brassy yellow, and reflects the differences in its composition, from 21.7 to 68.1 atom \% Au. Argentite, coexisting with pyrrhotite, is present in trace amounts and also infills cracks in pyrite. Native bismuth occurs in small veinlets, replacing arsenopyrite and pyrite. It coexists together with chalcopyrite, galena and pyrrhotite, and its size ranges generally from 30 to $50 \mu \mathrm{m}$, and up to as much as $600 \mu \mathrm{m}$. It commonly shows strong anisotropism. Smoky calcite and quartz were precipitated during stage III, which is barren of sulfide phases.

\section{FLUID INCLUSIONS}

\section{Petrography of fluid inclusions}

Quartz and calcite from each stage of mineralization were selected for a fluid-inclusion study. The inclusionrich quartz is generally semitransparent and forms subhedral to euhedral crystals. The associated calcite is usually too smoky for a study of inclusions, but the grains of calcite used for analysis are coarse-grained, transparent crystals. Petrography and subsequent measurements of inclusions were focused on closely associated groups or trails of inclusions with visually identical phase-ratios and similar shape. Their sizes vary from 5 to $30 \mu \mathrm{m}$.

Fluid inclusions can be classified into four types based on the number of phases, degree of filling at room temperature, and phase variations during heating and freezing experiments (Fig. 4). Type-I inclusions are liquid-rich and aqueous, consisting of a liquid and a vapor phase with degree of filling of 75 to $90 \mathrm{vol} . \%$. These inclusions homogenize to the liquid phase upon heating and do not contain daughter minerals. But some unknown phases are included, such as hexagonal crystals in the calcite and platy and irregularly shaped crystals in quartz, and they exhibit a high birefringence and a large difference in indices of refraction. The liquid-rich inclusions commonly occur as clusters in the individual domains, or are randomly distributed in the core of quartz crystals. The inclusions are divided into two types on the basis of whether they begin to melt below or above the temperature of the $\mathrm{NaCl}-\mathrm{H}_{2} \mathrm{O}$ eutectic, $-21.2^{\circ} \mathrm{C}$ (Davis et al. 1990). They are designated as type IA and type IB, respectively. These two types are distinguishable only by freezing experiments and do not show any other different features at room temperature. Type-IA inclusions are observed only in stage-I miner- alization, whereas type-IB inclusions occur both in stage-I and stage-II minerals.

Type-II inclusions are vapor-rich, consisting of a liquid and a vapor phase comprising $70-85 \%$, and are produced only during stage II. They homogenize to the vapor phase during heating, and neither liquid $\mathrm{CO}_{2}$ nor $\mathrm{CO}_{2}$ clathrate was observed during the freezing experiments. Though vapor-rich inclusions are also visible with liquid-rich inclusions under the microscope, the possible coeval trapping of the assemblage is uncertain. However, coexistence of vapor-rich inclusions and polyphase inclusions of type IV in trails more strongly supports the entrapment of a boiling fluid in vein quartz of stage II (Fig. 4). This relationship indicates that liquid-rich inclusions are earlier than the trails containing simultaneously trapped polyphase and vapor-rich inclusions.

Type-III inclusions contain $\mathrm{CO}_{2} \pm \mathrm{CH}_{4}$ and three phases (liquid $\mathrm{CO}_{2}$, aqueous liquid, and vapor) at room temperature. The $\mathrm{CO}_{2}$ phase homogenizes to the vapor phase, and total homogenization occurs by vapor-phase expansion as well. Upon heating, some inclusions decrepitated prior to homogenization. The inclusions occur as clusters or are randomly distributed, together with type-I aqueous inclusions, and some show pseudosecondary features. Thus, at least the type-III inclusions could not predate the type-I inclusions. However, no direct cross-cutting relationships were observed between trails containing $\mathrm{CO}_{2}$-bearing inclusions and trails containing type-II and type-IV inclusions in stage-II assemblages. Type-IV inclusions are polyphase and consist of liquid, vapor, and solid phases, such as halite and sylvite. This type of inclusion is found only in stageII mineralization, and is closely associated with gas-rich inclusions (type II) forming trails. Some solid phases are optically anisotropic and show an irregular shape. In all of the fluid inclusions, solid phases dissolved first and homogenization followed by disappearance of the vapor bubble.

\section{Microthermometric data}

Low-temperature changes in phases present were measured first to minimize the possibility of decrepitation of the inclusions. About one hundred and seventy inclusions were measured in freezing experiments. The following data on salinity are expressed in wt. $\% \mathrm{NaCl}$ equivalents. Type-IA inclusions began to melt between -62.2 and $-21.3^{\circ} \mathrm{C}$ (Fig. 5), which indicates that the fluids are not composed merely of $\mathrm{H}_{2} \mathrm{O}$ and $\mathrm{NaCl}$; instead, other cations are probably present in solution, such as $\mathrm{K}, \mathrm{Ca}, \mathrm{Fe}$, and $\mathrm{Mg}$ (Crawford 1981). Clynne \& Potter (1977) demonstrated that if the salinity of saline fluids in nature were converted to $\mathrm{NaCl}$ equivalents, the difference would not exceed 5\%. Therefore, we calculated the salinity of type-IA fluid inclusions according to Oakes et al. (1990), i.e., on the basis of the system of $\mathrm{H}_{2} \mathrm{O}-\mathrm{NaCl}-\mathrm{CaCl}_{2}$, that of type-IB and type-II inclusions 
by freezing points for aqueous sodium chloride solutions (Potter et al. 1978), and that of $\mathrm{CO}_{2}$-bearing typeIII inclusions by clathrate-melting temperature (Darling 1991). The salinity of the fluid in inclusions containing halite and sylvite as daughter minerals can be determined by dissolution of these daughter minerals (Potter et al. 1977, Sterner et al. 1988). However, the unknown phases in some type-I inclusions do not change upon heating, even above $550^{\circ} \mathrm{C}$, suggesting that they are not true daughter minerals. Similarly, the anisotropic minerals in type-IV inclusions remained unchanged even above temperatures of $550^{\circ} \mathrm{C}$.

With these results, the salinities of fluid inclusions are summarized by their stages and types as follows (Fig. 6); 13.1-28.0 wt.\% for type IA, 2.6-21.0 wt.\% for type IB, 2.8-5.2 wt.\% for type III at stage I, and 3.919.3 wt. $\%$ for type IB, $1.5-8.1 \mathrm{wt} . \%$ for type II, 1.6-5.5 wt.\% for type III, 27.6-49.3 wt.\% for type IV at stage II. The results indicate that relatively high-salinity fluids were involved in the mineralization process during all stages.
The melting temperature of $\mathrm{CO}_{2}$-bearing type-III inclusions, $\mathrm{T}_{\mathrm{m}(\mathrm{CO} 2)}$ which should be $-56.6^{\circ} \mathrm{C}$ for pure $\mathrm{CO}_{2}$, is between -60.4 and $-56.7^{\circ} \mathrm{C}$ (Fig. 7A), and indicates that other gases are present, usually $\mathrm{CH}_{4}$ or $\mathrm{N}_{2}$, which correspond to below 0.1 mole $\% \mathrm{CH}_{4}$ (Higgins 1980, Burruss 1981). Such amounts of other gases would cause little effect on the salinity (Collins 1979). Some fluid inclusions in samples of vein quartz have temperatures of clathrate melting above $10.0^{\circ} \mathrm{C}$ (Fig. 7C), which can be also ascribed to the presence of $\mathrm{CH}_{4}$ in the fluid inclusions (Collins 1979, Burruss 1981). Neglecting the presence of the $\mathrm{CH}_{4}$ clathrate, which acts to raise the melting temperature of the clathrate, the corresponding salinities are calculated to be less than 5.5 wt.\%. Homogenization of the carbonic phase to vapor occurred between the temperatures of +22.5 to $+30.7^{\circ} \mathrm{C}$, indicating a low density of $\mathrm{CO}_{2}$ (Fig. 7B). The range of $\mathrm{T}_{\mathrm{h}-\mathrm{CO} 2}$ values within a single grain of quartz indicates that the density of the $\mathrm{CO}_{2}$ phase varied during the entrapment of the fluids.
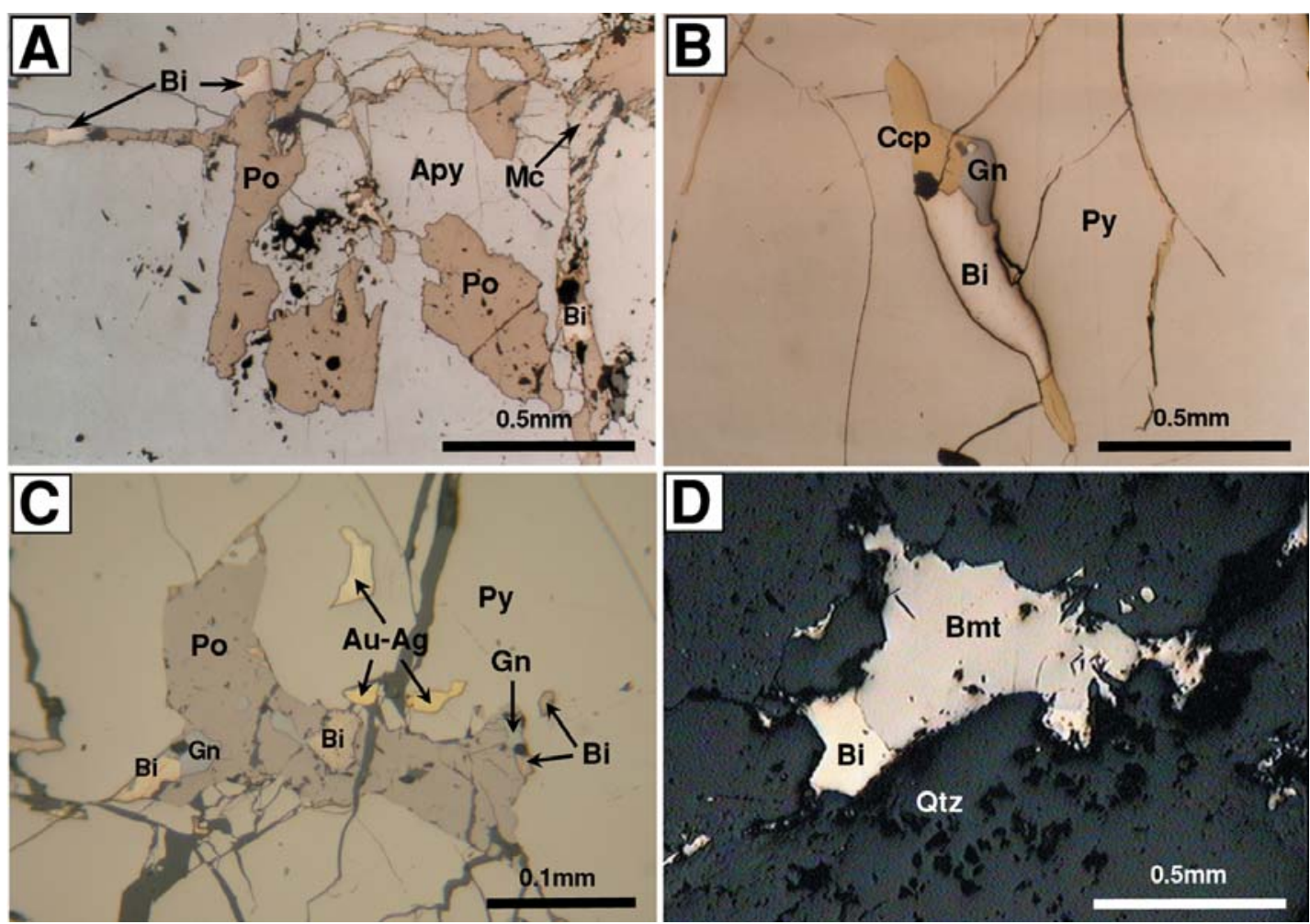

FIG. 3. Microphotographs showing the paragenesis of ore minerals from the Nakdong deposits. A. Arsenopyrite (Apy) replaced by pyrrhotite $(\mathrm{Po})$ and native bismuth $(\mathrm{Bi})$, marcasite $(\mathrm{Mc})$ formed from pyrrhotite. B. Pyrite $(\mathrm{Py})$ replaced by the assemblage of chalcopyrite (Ccp), galena ( $\mathrm{Gn})$ and native bismuth. $\mathrm{C}$. $\mathrm{Au}-\mathrm{Ag}$ alloy $(\mathrm{Au}-\mathrm{Ag}$ ) associated with pyrrhotite, native bismuth and galena in pyrite. D. Coexistence of bismuthinite (Bmt) with native bismuth. 

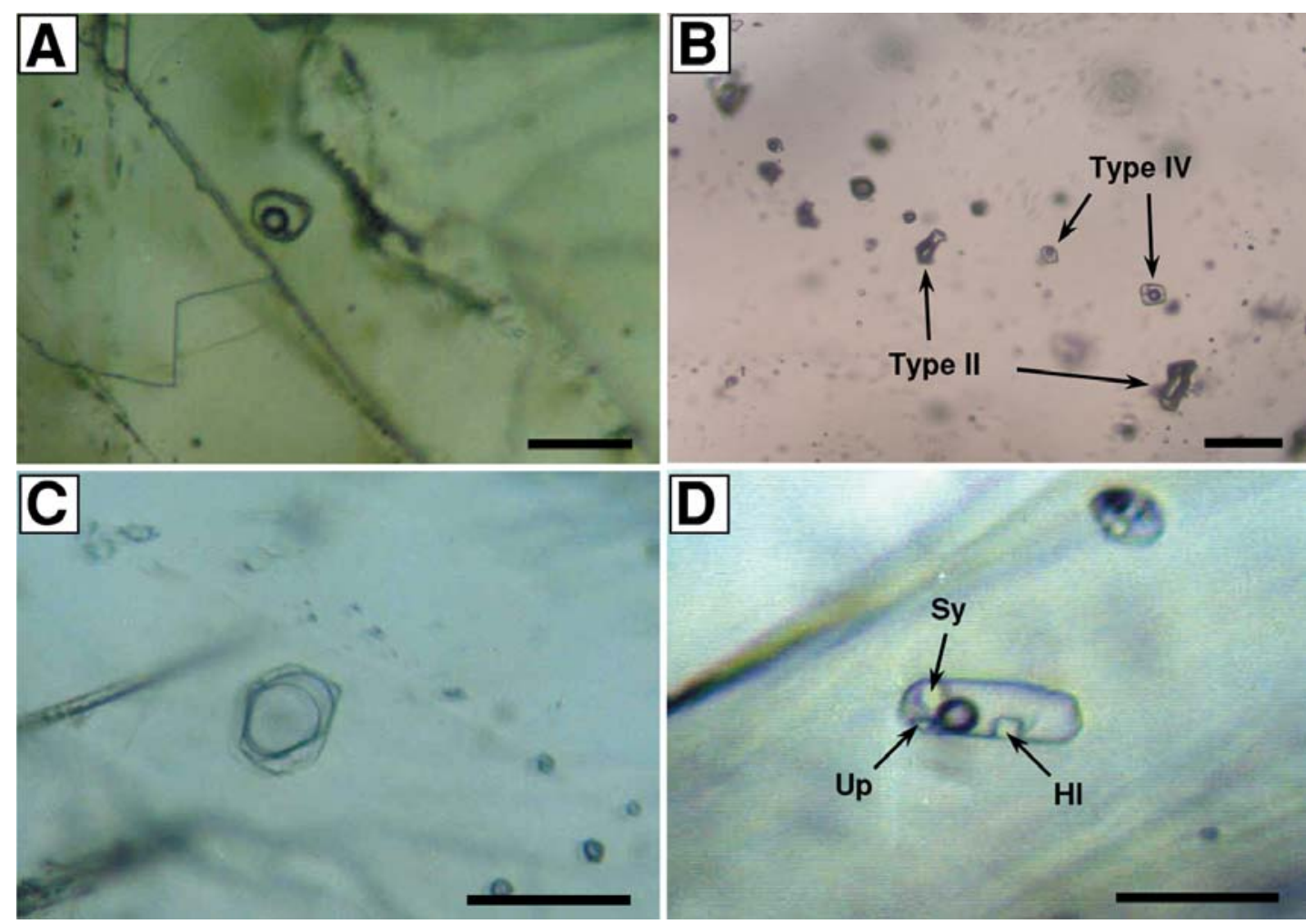

FIG. 4. Microphotographs showing the types and occurrences of fluid inclusions from the Nakdong deposits. A. Type-IA inclusion in stage-I calcite. B. Inclusion trail consisting of type-II and type-IV inclusions in stage-II quartz. C. Type-III $\mathrm{CO}_{2}-$ bearing inclusion in stage-II quartz. D. Halite (Hl), sylvite (Sy) and unknown phase (Up) in type-IV inclusion in stage-II quartz. Scale bars: $20 \mu \mathrm{m}$.

The salinity of type-IV fluid inclusions can be obtained using the melting temperature of halite and sylvite. In halite-only fluid inclusions, the melting of halite ranges from 88 to $318^{\circ} \mathrm{C}$ (Table 1 ). In the sylviteand halite-bearing inclusions, sylvite was the first phase to melt between 50 and $157^{\circ} \mathrm{C}$, whereas halite melted from 130 to $281^{\circ} \mathrm{C}$, as can be inferred from the $\mathrm{H}_{2} \mathrm{O}-$ $\mathrm{NaCl}-\mathrm{KCl}$ diagram in Figure 8. On the basis of these data, we contend that the fluids were comparatively enriched in sodium rather than potassium, with a $\mathrm{Na} /$ $(\mathrm{Na}+\mathrm{K})$ value of between 0.51 and 0.75 . The salinity of the halite-only bearing inclusions ranges from 27.6 to $39.6 \mathrm{wt} . \%$, whereas for halite- and sylvite-bearing inclusions, it ranges from 36.9 to $49.3 \mathrm{wt}$.\%. These calculated total salinities are not corrected for the effect of other salts, such as $\mathrm{MgCl}_{2}, \mathrm{FeCl}_{2}$, and $\mathrm{CaCl}_{2}$, which may also be present.

The temperatures of total homogenization measured for two hundred and forty-nine inclusions of the various stages and types are $315-416^{\circ} \mathrm{C}$ for type IA, 283$402^{\circ} \mathrm{C}$ for type IB, $316-409^{\circ} \mathrm{C}$ for type III in stage I, and $278-385^{\circ} \mathrm{C}$ for type IB, $312-372^{\circ} \mathrm{C}$ for type II, 306$395^{\circ} \mathrm{C}$ for type III, $222-389^{\circ} \mathrm{C}$ for type IV in stage II (Fig. 9). The homogenization temperatures decreased little from stage-I to stage-II mineralization.

\section{StABLE Isotopes}

Carbon and oxygen isotopes of carbonates and of fluid inclusion $\mathrm{CO}_{2}$ in quartz.

Analytical results for the fresh limestone, silicified limestone, and vein calcite are presented in Table 2 and Figure 10. Fresh platy limestone from the Maggol Formation has $\delta^{13} \mathrm{C}$ and $\delta^{18} \mathrm{O}$ values of +2.3 to $+4.4 \%$ and +17.5 to $+22.4 \%$ o, respectively. These values fall close to the field of marine limestone (Keith \& Weber 1964). Calcite from the silicified limestone is distinctly depleted relative to the fresh limestone, and the relevant values range from -2.5 to $+1.3 \%$ for carbon and +13.3 to $+18.3 \%$ for oxygen. Four possible explanations for the depletion trends are: (1) exchange of ${ }^{18} \mathrm{O}$ of fresh 
limestone with any ${ }^{18} \mathrm{O}$-depleted rock units, (2) preferential loss of ${ }^{18} \mathrm{O}$ and ${ }^{13} \mathrm{C}$ during volatilization process induced by igneous intrusion (Cook et al. 1997), (3) progressive mixing with external fluids of low- ${ }^{18} \mathrm{O}$ composition (Bowman et al. 1985), and (4) any combination of the above three possibilities.

Case (1) is considered the least likely because in the study area, there are no appropriate rock units, except limestone, which could influence the isotopic depletions. Many investigators have demonstrated that $\mathrm{CO}_{2}$ liberated from the volatilization of carbonates during igneous intrusion is significantly richer in ${ }^{18} \mathrm{O}$ as well as ${ }^{13} \mathrm{C}$ relative to the original carbonates, which would cause depletion of $\delta^{18} \mathrm{O}$ and $\delta^{13} \mathrm{C}$ values of the residual carbonate minerals (Valley 1986). The extent of isotopic depletion in the carbonate rocks depends on the temperature of reaction, the amount of volatilization, and the degree to which escaping fluids are controlled by Rayleigh distillation. The extent of ${ }^{13} \mathrm{C}$ depletion due to volatilization can be calculated on the basis of simple mass-balance equations and Rayleigh fractionation. In a closed system, the depletion during decarbonation is given by:

$$
\delta^{13} \mathrm{C}_{\mathrm{cc}}-X_{\mathrm{CO} 2}\left(\Delta^{13} \mathrm{C}_{\mathrm{CC}-\mathrm{CO} 2}\right)=\delta^{13} \mathrm{C}_{\text {system }}
$$

For an open system, the relevant equation is

$$
\mathrm{R}^{\mathrm{f}} / \mathrm{R}^{\mathrm{i}}=\mathrm{F}^{\alpha-1}
$$

$\mathrm{R}^{\mathrm{f}}$ and $\mathrm{R}^{\mathrm{i}}$ are the ${ }^{13} \mathrm{C} /{ }^{12} \mathrm{C}$ values after and before reaction, respectively, and $\mathrm{F}$ is the fraction of carbon remain-

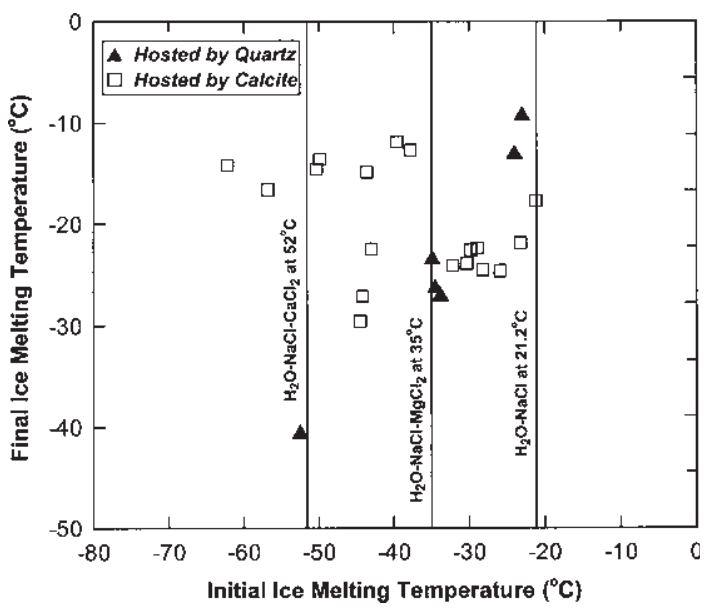

FIG. 5. Initial temperature of ice melting versus final temperature of ice melting for type-IA fluid-inclusions from the Nakdong deposits, with eutectic temperatures of some chloride assemblages from Davis et al. (1990). ing in the rock. The fractionation equation for calcite suggested by Chacko et al. (1991) was used for the above calculation.

The initial isotopic composition was assumed to be $+3.4 \%$ for $\delta^{13} \mathrm{C}$ and $+20.0 \%$ of for $\delta^{18} \mathrm{O}$, which are the average values of the fresh Maggol limestone in the study area. Temperatures for our calculations were based on the temperature of $630^{\circ} \mathrm{C}$ from the hornblende geothermometer for the Jeongseon granitic rocks (Hur 1997), and $410^{\circ} \mathrm{C}$ from the temperature of maximum homogenization of the fluid inclusions. We calculated the ${ }^{18} \mathrm{O}$ variation in accordance with the normal calcsilicate decarbonation trend, and disregarded the possibilities of decarbonation-silicate disequilibrium or of silicate-absent decarbonation suggested by Valley (1986). In the normal case of calc-silicate decarbonation, all carbon in the carbonate is assumed to have been released as $\mathrm{CO}_{2}$, whereas only $40 \%$ of the mass of oxygen is liberated after the decarbonation process is completed. The results of the calculations are shown in Table 3.

The depletion trend inferred is not in full accord with the values calculated for the volatilization process. Silicified limestone in the study area generally contains more than $60 \%$ calcite. However, the calculated isotope compositions of limestone with the remaining carbon fraction of 0.6 , correspond to $+1.6-+1.7 \%$ o for $\delta^{13} \mathrm{C}$

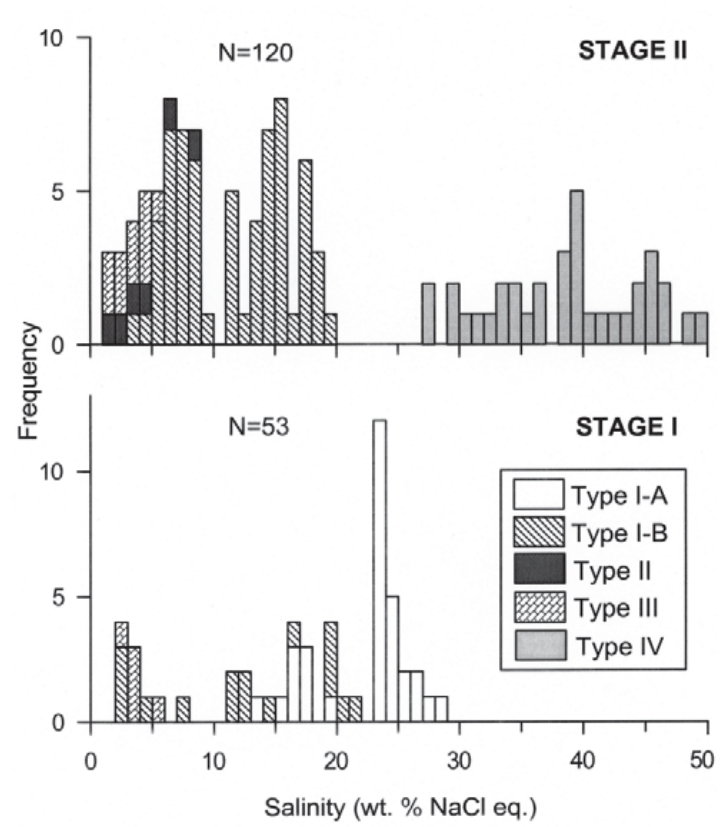

FIG. 6. Histograms showing the salinity of fluid inclusions in quartz from the Nakdong deposits. 


\section{A. $\mathrm{Tm}-\mathrm{CO}_{2}$}

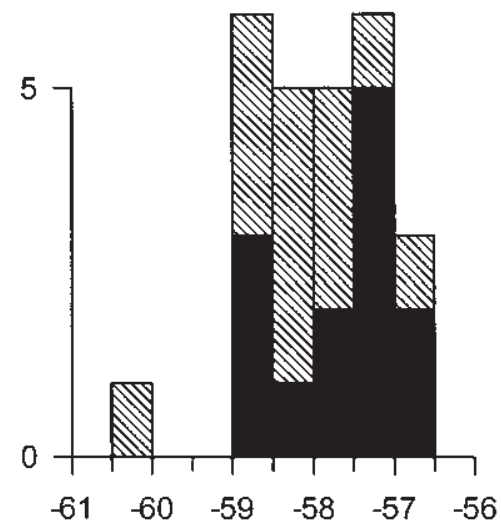

B. Th- $\mathrm{CO}_{2}$

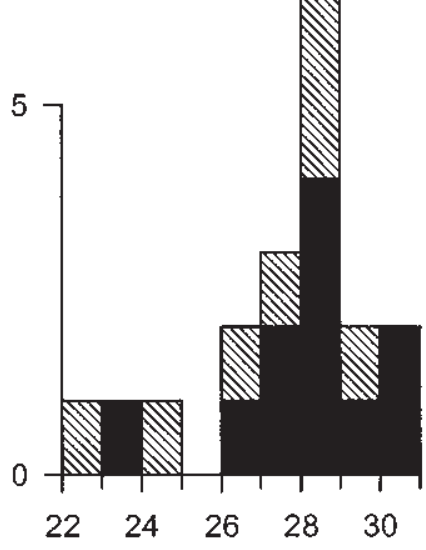

C. Tm-clath

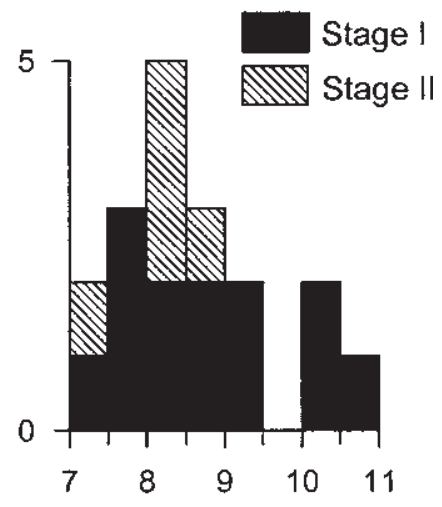

Temperature $\left({ }^{\circ} \mathrm{C}\right)$

FIG. 7. Temperature of melting $\left(A: T_{m-C O}\right)$ and homogenization $\left(B: T_{h-C O 2}\right)$ of the carbonic phase, and of clathrate melting $(C$ : $\mathrm{T}_{\mathrm{m} \text {-clath }}$, in type-III fluid inclusions from the Nakdong deposits.

and $+18.4-+18.8 \%$ or for $\delta^{18} \mathrm{O}$ in an open system, and those values deviate significantly even from the average isotopic value of the silicified limestone, $-0.9 \%$ o for carbon and $+15.2 \%$ o for oxygen. These results indicate that the magnitude of ${ }^{13} \mathrm{C}$ and ${ }^{18} \mathrm{O}$ depletion due only to Rayleigh volatilization in the study area does not seem sufficient to cause isotopic depletions measured for the silicified limestone. Thus the presence of external fluids, a magmatic or meteoric fluid, is required to promote isotopic fractionation during the interaction with carbonate rocks.

Samples of vein calcite from stage II have $\delta^{13} \mathrm{C}$ values of -5.7 to $-3.6 \%$ and $\delta^{18} \mathrm{O}$ values of +11.3 to $+15.2 \%$. The carbon species in the mineralizing fluids, which precipitated carbonate minerals, are known to be dominated by the $\mathrm{CO}_{2}$ phase (Taylor 1986, Mattey et al. 1990). From the homogenization temperature and isotopic fractionation factor suggested by Chacko et al. (1991), carbon isotope compositions of $\mathrm{CO}_{2}$ equilibrated with calcite are calculated to be between -2.9 and $-0.8 \%$ for stage-II vein calcite. Values of $\delta^{18} \mathrm{O}_{\mathrm{H} 2 \mathrm{O}}$ calculated from the relationship of Zheng (1999) range from +6.3 to $+8.7 \%$ o. These carbon and oxygen isotopic compositions correspond to the common range of magmatic fluids (Ohmoto \& Goldhaber 1997). Thus, fluids of plausible magmatic origin related to the vein formation, which have much lower isotopic values compared to the limestone, seem to have contributed to the isotopic depletion in carbon as well as oxygen in the carbonate rocks through fluid-rock interaction. A similar magmatic contribution to carbon and oxygen isotope depletion in the carbonate rocks was reported from the

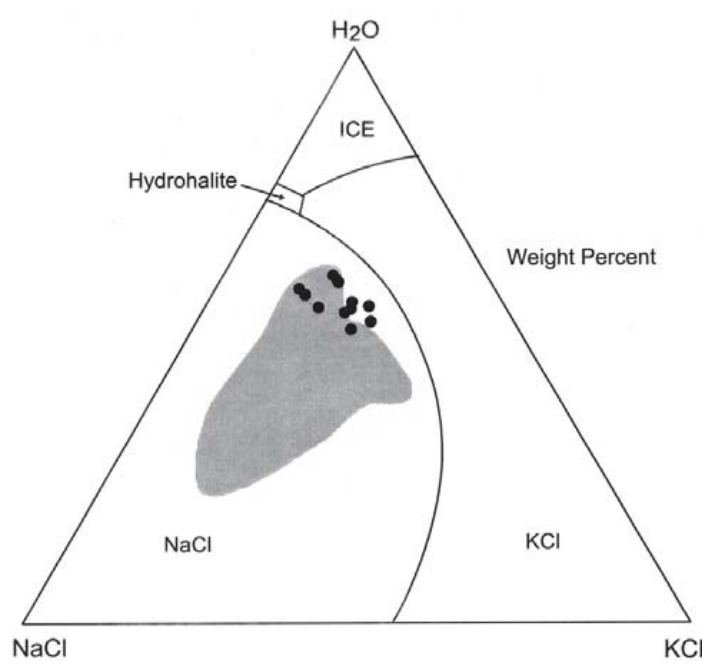

FIG. 8. Plot of the system $\mathrm{NaCl}-\mathrm{KCl}-\mathrm{H}_{2} \mathrm{O}$ showing the compositional field for fluid inclusions from several porphyry copper deposits (shaded area; Roedder 1984) and the Nakdong deposits (solid circles).

Sangdong tungsten deposits in the Taebaegsan region (Kim et al. 1988).

The $\mathrm{CO}_{2}$ of fluid inclusions extracted by crushing vein quartz from stage II has $\delta^{13} \mathrm{C}$ values of -0.3 to $+0.2 \%$ o, which are slightly higher than those of $\mathrm{CO}_{2}$ 
equilibrated with stage-II vein calcite. As primary magmatic $\mathrm{CO}_{2}$ in hydrothermal fluids is probably lower than $-3.0 \%$ in the Nakdong deposits, the $\delta^{13} \mathrm{C}$ values from the inclusions are believed to possibly represent a mixture of juvenile $\mathrm{CO}_{2}$ plus $\mathrm{CO}_{2}$ from decarbonation reaction of carbonate rocks.

\section{Oxygen and hydrogen isotopes of vein quartz and the inclusion fluids}

Samples of vein quartz from stage II were also analyzed, and found to range from +13.9 to $+16.2 \%$ of their $\delta^{18} \mathrm{O}$ values (Table 2). The values of $\delta^{18} \mathrm{O}$ of $\mathrm{H}_{2} \mathrm{O}$ in equilibrium with each sample of quartz were calculated to be +6.8 to $+8.8 \%$ at the relevant temperatures derived from fluid inclusions in Table 2 using the quartz$\mathrm{H}_{2} \mathrm{O}$ isotope fractionation equation of Zheng (1993). They are very similar to the values determined from calcite. Thus, the isotopic compositions of fluids seem to have remained constant during the precipitation of calcite and quartz within stage II.

As the fluids extracted from inclusions originated from a variety of inclusion types and may possibly con-

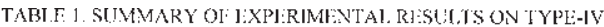

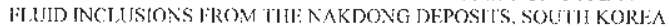

\begin{tabular}{|c|c|c|c|c|c|c|c|}
\hline $\begin{array}{l}\text { Ifost } \\
\text { minctal }\end{array}$ & $\mathrm{T}_{\text {til }}$ & $\mathrm{T}^{\mathrm{ink}} \mathrm{KCi}$ & $\begin{array}{l}\text { Homo } \\
{ }^{\circ} \mathrm{C}\end{array}$ & $\begin{array}{l}\text { Nacl } \\
w 10 \%\end{array}$ & $\begin{array}{l}\mathrm{KCI} \\
\mathrm{wt} \%\end{array}$ & $\begin{array}{c}\mathrm{Na} / \\
(\mathrm{Na}+\mathrm{K})\end{array}$ & Sal. \\
\hline \multirow[t]{8}{*}{ Quatly } & 197 & - & 325 & $\$ 1.7$ & - & - & 31.7 \\
\hline & 270 & - & 300 & 36.0 & - & - & 36.0 \\
\hline & 302 & - & 326 & 38.3 & - & - & 38.3 \\
\hline & 243 & - & 360 & 34.2 & - & - & 34.2 \\
\hline & 268 & - & 324 & 35.8 & - & - & 358 \\
\hline & 318 & - & .345 & 39.6 & - & - & 39.6 \\
\hline & 202 & - & 327 & 32,0 & - & - & 32.0 \\
\hline & 229 & - & 334 & 33.4 & - & - & 33.4 \\
\hline \multirow[t]{26}{*}{ Calcito } & 234 & - & 293 & 34.0 & - & - & 34.0 \\
\hline & 176 & . & 241 & 30.8 & - & - & 30.8 \\
\hline & 154 & - & 249 & 29.8 & - & - & 29.8 \\
\hline & 152 & $=$ & 243 & 29.8 & - & - & 29.8 \\
\hline & 88 & - & 287 & 27.6 & . & - & 27.6 \\
\hline & 91 & - & 278 & 27.7 & - & - & 27.7 \\
\hline & 154 & - & 298 & 38.5 & - & - & 38.5 \\
\hline & 266 & 80 & 288 & 26.8 & 17.8 & 0.66 & 44.6 \\
\hline & 233 & 147 & 340 & $2 E .5$ & $2 \overline{3} .4$ & 0,52 & 469 \\
\hline & 168 & 81 & 241 & 2 2โ.2 & 18.3 & 0.60 & 39.5 \\
\hline & 156 & 76 & 242 & 21.0 & 17.6 & (1). 601 & 386 \\
\hline & 165 & 80 & 241 & 21.2 & 18.1 & 0.60 & 39.3 \\
\hline & 168 & $\$ 1$ & 239 & 21.2 & 18.3 & 0.60 & 39.5 \\
\hline & 130 & 63 & 240 & 20.8 & 16.1 & 069 & 369 \\
\hline & 195 & 72 & 260 & 23.2 & 16.7 & $0 .(n+4$ & 39.9 \\
\hline & 201 & 81 & 262 & 23.0 & 17.8 & 0,62 & 40.8 \\
\hline & 211 & 138 & 322 & 20.5 & 24.8 & 0.51 & 453 \\
\hline & $2+2$ & 157 & 337 & 21.6 & 26.4 & 0.51 & 48.1 \\
\hline & 279 & 145 & 319 & 25.2 & 24.1 & 0.57 & 49.3 \\
\hline & 275 & 61 & 292 & 29.1 & 14.2 & 0.72 & 43.3 \\
\hline & 281 & 87 & 301 & 28.2 & 17.3 & 0.68 & 45.5 \\
\hline & 228 & 116 & 245 & 22.7 & 21.9 & 0.57 & $4-4.6$ \\
\hline & 24.3 & 122 & 250 & 23,5 & 22.3 & 0.57 & 45.8 \\
\hline & 204 & 83 & 312 & 23.0 & 18.1 & $0.6 ?$ & 41.1 \\
\hline & 272 & 50 & 206 & 29.5 & 12.8 & 0.75 & 42.3 \\
\hline & 257 & 120 & 321 & 24.7 & 21.7 & 0.59 & 46.3 \\
\hline
\end{tabular}

Homo: temperature of homogenization. Sal.: total salinity. tain grain-boundary $\mathrm{H}_{2} \mathrm{O}$ and some other secondary inclusions, the measured $\delta \mathrm{D}$ values are composite values of all $\mathrm{H}_{2} \mathrm{O}$ present, and range from -88 to $-76 \%$. The $\delta \mathrm{D}$ values of most examples of magmatic water typically range from -85 to $-50 \%$ o (Taylor \& Sheppard 1986). However, the range of $\delta D$ values of paleometeoric waters during the Jurassic and Cretaceous in South Korea is assumed to be -143 to $-61 \%$ o (Shelton et al. 1988, 1990). Therefore, although the $\delta \mathrm{D}$ values from the Nakdong deposits could represent magmatic fluids, they could not exclude the possibility of infiltration of meteoric water that was equilibrated isotopically with nearby igneous rocks at high temperatures and low water: rock ratios. Oxygen and hydrogen isotope compositions from the quartz and its fluid inclusions are, therefore, generally supportive of a contribution from magmatic fluid with possible involvement of meteoric water to arsenic-bismuth mineralization in the Nakdong deposits.

\section{Sulfur isotopes}

Values of $\delta^{34} \mathrm{~S}$ vary from +4.3 to $+4.7 \%$ at stage I and from +2.1 to $+4.8 \%$ at stage II (Table 4 ). It is important to identify the sulfur species involved in the mineralization in order to define the origin of sulfur in the sulfide minerals. Generally, the quantitatively prevailing sulfur species in mineralizing fluids below

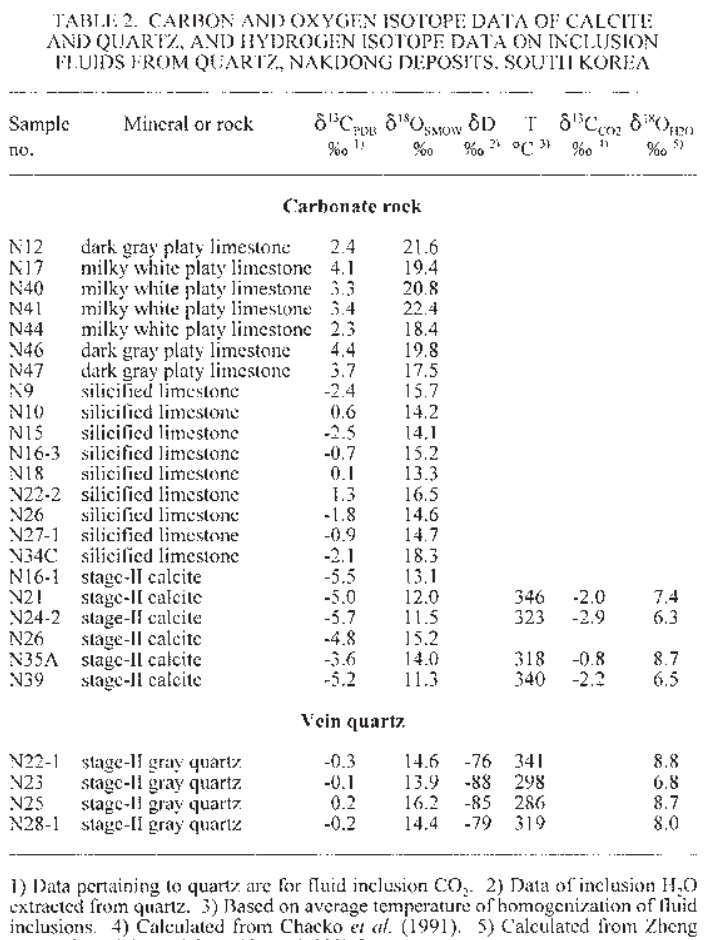

incluvions 4) Calculded from Chacko at (1991) 5) Galculated fom zhane (1999) for calcits and from 2 hong (1995) for quartz 
$350^{\circ} \mathrm{C}$ are $\mathrm{H}_{2} \mathrm{~S}, \mathrm{HS}^{-}$, and $\mathrm{SO}_{4}{ }^{2-}$. As isotopic partitioning behavior between $\mathrm{H}_{2} \mathrm{~S}$ and $\mathrm{HS}^{-}$is insignificant, $\mathrm{H}_{2} \mathrm{~S}$ and $\mathrm{SO}_{4}{ }^{2-}$ can be assumed representative for sulfur species included in the mineralizing fluids (Ohmoto \& Goldhaber 1997).

Considering the temperature of formation, the amount of FeS in sphalerite (+16.7 to +19.4 mole \%), and the fugacity of oxygen inferred from the mineral assemblage, the prevailing sulfur species in the mineralizing fluids was $\mathrm{H}_{2} \mathrm{~S}$ (Fig. 11). Therefore, sulfur isotope compositions of the sulfides are represented by $\delta^{34} \mathrm{~S}_{\mathrm{H} 2 \mathrm{~S}}$ (Table 4), and are calculated by the isotope fractionation factor of Ohmoto \& Goldhaber (1997). For the calculation of $\delta^{34} \mathrm{~S}_{\mathrm{H} 2 \mathrm{~S}}$ for bismuthinite, the stibnite fractionation equation was used owing to the solid-solution relation between the two phases. The results show that $\delta^{34} \mathrm{~S}_{\mathrm{H} 2 \mathrm{~S}}$ increased slightly from stage I $(+3.2$ to $+4.4 \%$ o $)$ to stage II $(+4.1$ to $+4.8 \%$ o). Figure 11 indicates that there is little difference in sulfur isotope compositions between sulfur species calculated from sulfide minerals $\left(\delta^{34} \mathrm{~S}_{\mathrm{H} 2 \mathrm{~S}}\right)$ and mineralizing fluids $\left(\delta^{34} \mathrm{~S}_{\text {fluid }}\right)$. Therefore, the similarity between $\delta^{34} S_{\text {fluid values of mineralizing }}$ fluids and $\delta^{34} \mathrm{~S}_{\mathrm{H} 2 \mathrm{~S}}$ values of sulfide minerals suggests that sulfur isotope compositions of mineralizing fluids increased slightly from stage I to stage II, with little variance in the isotope composition, which corresponds to the magmatic range (Ohmoto \& Goldhaber 1997). Similarly, Kim \& Nakai (1982) and Kim et al. (1988) have concluded that the sulfur species of sulfide minerals with isotope compositions between +2 and $+7 \%$, from the metallic ore deposits in the Taebaegsan

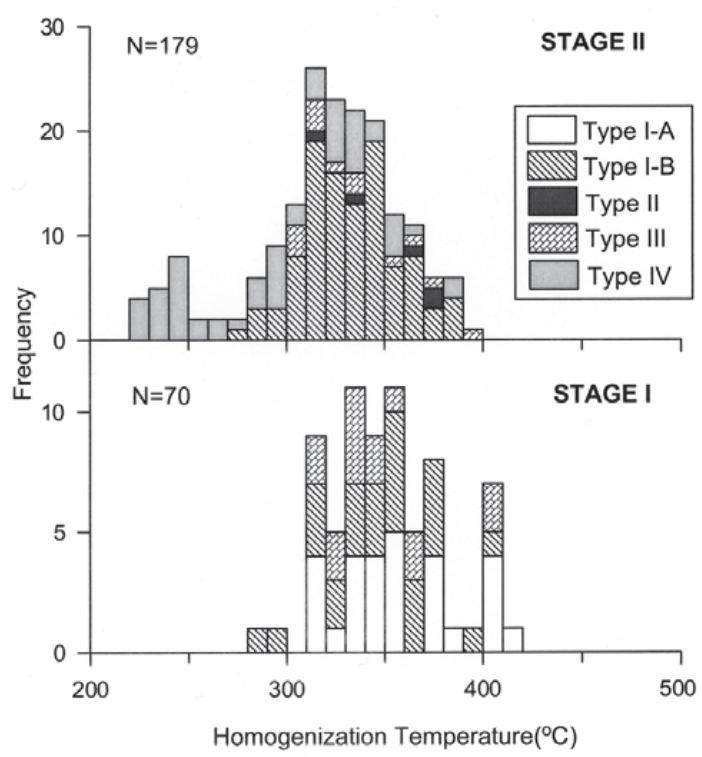

FIG. 9. Histograms of homogenization temperatures for fluid inclusions from the Nakdong deposits.
Metallogenic Belt, originated from felsic igneous rocks. Thus a magmatic derivation of sulfur can be compatible with the high-temperature and high-salinity signature of the primary hydrothermal fluids.

\section{Genetic Considerations}

\section{Fluid evolution}

In a broad sense, the fluids that are most likely to be associated with arsenic and bismuth mineralization are type-I inclusions $\left(\mathrm{H}_{2} \mathrm{O}-\mathrm{NaCl} \pm \mathrm{CaCl}_{2}\right)$ in the Nakdong deposits. The only geologically common constituent in

TA[BLE 3. 'SC AND 'OO DEPLETTONS OF IIMESTYNIS DURTNG THE VOLATHITATION BROCISS, NAKOONG JIEPOSITS, SOUTH KOREA

\begin{tabular}{|c|c|c|c|c|}
\hline \multirow{2}{*}{$\begin{array}{l}\text { Mole } \\
\text { fraction } \\
\text { of carben } \\
\text { remaining } \\
\text { in the } \\
\text { systitus }\end{array}$} & \multicolumn{2}{|c|}{$\begin{array}{l}0^{13} \mathrm{C} \text { and } 8^{18} \mathrm{O} \text { of } \\
\text { rcsidual calcite } \\
\text { in closed syslem }\end{array}$} & \multicolumn{2}{|c|}{$\begin{array}{l}\delta \mathrm{C} \text { and } \delta \mathrm{s}^{\mathrm{s}} \text { of } \\
\text { residual calcite } \\
\text { in open system }\end{array}$} \\
\hline & $8^{\prime} \cdot \mathrm{C}:-3.4 \%$ & $\delta^{1 \times} 0_{1} \cdot \cdots 20.0 \%(H)$ & $\delta^{1} C_{:}-3.4 \%$ & $80^{18}-20.6 \%$ \\
\hline ] & $3.4(3,4)$ & $20.0(20.0)$ & $3.4(3.4)$ & $20.0(200)$ \\
\hline 0.9 & $3.1(3.1)$ & $10.4(19.2)$ & $30(30)$ & $19.8(19.7)$ \\
\hline 0.8 & $2.7(2.8)$ & $18.9(18.5)$ & $2.6(2.6)$ & $19.5(19.4)$ \\
\hline 0.7 & $2.4(2.4)$ & $18.3(17.7)$ & $2.1(2.2)$ & $19.3(190)$ \\
\hline 0.6 & $200.1)$ & $17.8(17.0)$ & $1.6(1.7)$ & $190(187)$ \\
\hline 0.5 & $1.7(1.7)$ & $17.2(16.2)$ & $0.9(1.1)$ & $187(183)$ \\
\hline 0.4 & $1.3(1.4)$ & $16.7(15.5)$ & $0.1(0.3)$ & $18.4(17.9)$ \\
\hline 0.3 & $0.9(1.1)$ & $16.1(14.7)$ & $-0.9(-0.7)$ & $18.1(17.5)$ \\
\hline 0.2 & $0.6(0.7)$ & $15.6(14.0)$ & $-2.3(-2.0)$ & $17.8(17.0)$ \\
\hline 0.7 & $0.2(0.4)$ & $15.0(13.2\}$ & $-4.8(-4,4)$ & $17.5(16,6)$ \\
\hline 0.01 & $-0.1(0.1)$ & $14.5(125)$ & $-12.9(-12.1)$ & $97.1(16.1)$ \\
\hline
\end{tabular}

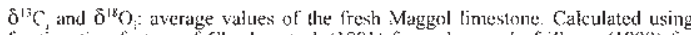
liactionation lactots of Chack of at. (1991) for carbon and of theng (1999) lot

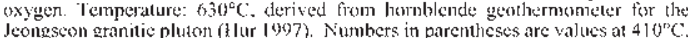

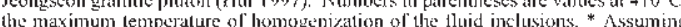
normal calc-silicated decirbonation (valley 1986 )

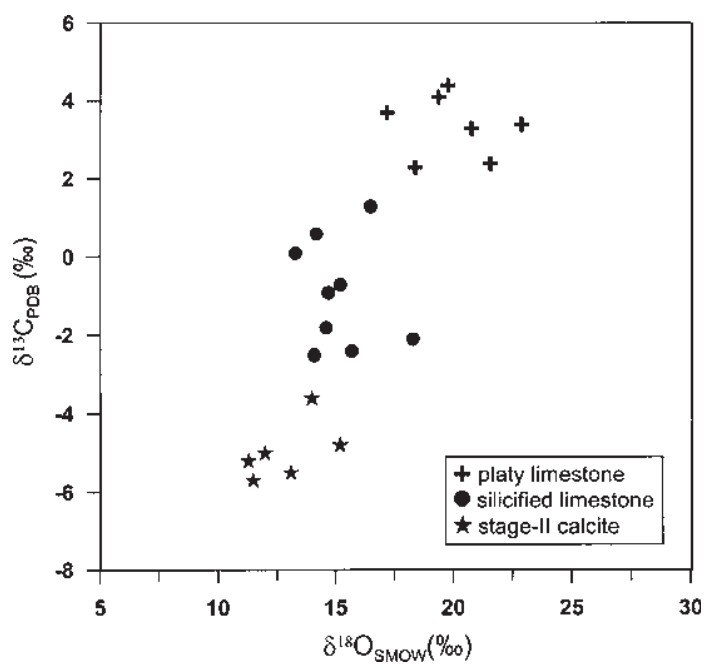

FIG. 10. Oxygen and carbon isotopic compositions for calcite in the Nakdong area. 
aqueous inclusions that will result in eutectic melting at temperatures as low as $-52^{\circ} \mathrm{C}$ is $\mathrm{CaCl}_{2}$ (e.g., Oakes et al. 1990, Li \& Naldrett 1993, Valenza et al. 2000), and the microthermometric behavior of type-IA inclusions in the Nakdong deposits seems to follow this system. Some inclusions showing lower temperature of melting than $-52^{\circ} \mathrm{C}$ could be due to either metastable behavior of the inclusions or to the addition of $\mathrm{MgCl}_{2}$ or $\mathrm{FeCl}_{2}$, which can lower the temperature to about $-60^{\circ} \mathrm{C}$ (Davis et al. 1990). However, $\mathrm{CaCl}_{2}$ daughter crystals have not been identified simply because the $\mathrm{CaCl}_{2}$ contents of the fluid inclusions may not have been close to saturation. The final temperatures of ice melting scatter over twenty degrees, and there is a general trend of lower initial temperatures of ice melting with increasing salinities, suggesting that $\mathrm{Ca}$ becomes a predominant cation as the salinity of the fluid inclusion increases (Fig. 5).

The origin of $\mathrm{Ca}$ in brines and hydrothermal fluids is often a matter of debate (Hanor 1994). The Ca-enriched nature of the fluids related to arsenic and bismuth mineralization in the Nakdong deposits seems to be affected by decarbonation processes of the immediate carbonate host-rocks, whereas some part of this Ca-rich fluid may be of magmatic origin (Burnham 1997). Though the occurrence of type-IA inclusions is concentrated at stage I, the occurrence of type-IB inclusions at stage II, as well as at stage I with higher initial temperatures of ice melting than $-21.2^{\circ} \mathrm{C}$ but still comparatively low temperatures of initial melting, indicates that the presence of lesser amounts of cations such as $\mathrm{Ca}$ continued into stage II, though $\mathrm{Na}$ is the dominant cation in these inclusions.

Similarly, the occurrence of carbonic fluid of typeIII inclusions was derived from a low-salinity homogeneous $\mathrm{H}_{2} \mathrm{O}-\mathrm{CO}_{2}$ fluid generated as a consequence of the decarbonation reactions of the carbonate wallrocks. Subsequent ingress of this carbonic fluid into the mineralizing fluid possibly occurred with addition of some magmatic component, as implied by the carbon isotopic signature. As $\mathrm{CO}_{2}$ liberated from decarbonation of carbonates is richer in ${ }^{18} \mathrm{O}$ and ${ }^{13} \mathrm{C}$ than the original carbonates (Valley 1986, Cook et al. 1997), $\delta^{13} \mathrm{C}$ values of $\mathrm{CO}_{2}$ extracted from fluid inclusions (i.e., that would be affected by the decarbonation reaction) from vein quartz of stage II are higher than those of $\mathrm{CO}_{2}$ equilibrated with stage-II vein calcite (Table 2). Analogous to the $\mathrm{CO}_{2}$ phase, the small amount of $\mathrm{CH}_{4}$ in type-III fluids is possibly attributed to localized reaction between hydrothermal fluids and graphitic or carbonaceous wallrocks (Bottrell et al. 1988), as well as to a magmatic contribution, but graphite was not observed in the carbonate rocks of the study area. The occurrence of $\mathrm{CH}_{4}$ over the two stages of mineralization corresponds to the reducing condition that is favorable to arsenic and bismuth precipitation. The continuity of $\mathrm{CO}_{2}$-bearing type-III inclusions from stage I to stage II seems to be independent of evolution of the primary magmatic fluids that are mostly likely to be associated with arsenic and bismuth mineralization. Even the occurrences of type-III fluid inclusions with type-I inclusions are insufficiently supported by either inclusion assemblages or petrographic relationships to demonstrate that there was fluid unmixing.

Hydrothermal fluids trapped at stage II show a clear bimodal distribution in salinities, with a similar range in temperature between low-density gaseous type-II fluids and high-density saline type-IV fluids (Fig. 12). The coexistence of different types of fluid (as trapped in type-II versus type-IV inclusions) within arrays of inclusions from individual grains of quartz from veins, and the contrasting total homogenization behavior into the vapor (type II) and liquid (type IV) phases over the similar range of temperatures, characterize the immiscibility of the mineralizing fluids at stage II in the Nakdong deposits. The bulk fluids of type I, with 11 wt. $\% \mathrm{NaCl}$ at stage II, thus intersected the solvus owing to pressure reduction when encountering the open spaces like faults, dyke walls, limestone bedding, or fissures, at which point the fluid separated into about $40 \mathrm{wt} . \%$ hypersaline fluid with vapor-rich low-salinity fluid (Fig. 13).

Temperature, pressure, and fugacity of sulfur during trapping

Given the evidence for fluid immiscibility at stage II of vapor-rich (type-II) inclusions $\left(\mathrm{T}_{\mathrm{h}}\right.$ in the interval 312 to $372^{\circ} \mathrm{C}$ ) and solid-bearing (type-IV) fluid inclusions, the homogenization temperature of fluid inclusions trapped at boiling conditions requires no pressure correction. With an average salinity of $11 \mathrm{wt} . \%$ for fluids in stage II, the pressures at the temperatures of homogenization $\left(312\right.$ to $\left.372^{\circ} \mathrm{C}\right)$ were calculated to be about 95 to 200 bars from the equation of state for the system $\mathrm{H}_{2} \mathrm{O}-\mathrm{NaCl}$ (Zhang \& Frantz 1987). Then, the depth of bismuth precipitation ranges from 990 to $2070 \mathrm{~m}$ under hydrostatic pressures, as supported by the presence of

\begin{tabular}{|c|c|c|c|c|c|}
\hline Slage & Sample yo. & Mineral & $\delta^{3+\mathrm{S}}(\%)$ & $\delta^{4} \mathrm{~S}_{1 \cdots}(\%)^{\circ}$ & $T\left({ }^{\circ} \mathrm{C}\right)^{* *}$ \\
\hline \multirow[t]{6}{*}{ I } & $N 13-5$ & Pyrite & 4.7 & 3.7 & 367 \\
\hline & N13-15 & $\begin{array}{l}\text { Assenopyrite } \\
\text { Pyrite }\end{array}$ & $\begin{array}{l}4.7 \\
4.3\end{array}$ & 3.2 & $\begin{array}{l}-961 \\
327\end{array}$ \\
\hline & & Sphaserile & 4.7 & 4.4 & 327 \\
\hline & Nisi-20 & Pyrite & 4.3 & 32 & 344 \\
\hline & & Arsclopyrite & 4.6 & & 344 \\
\hline & $\mathrm{N} 338 \mathrm{C}$ & Sphallerile & 4.3 & 4.0 & $\$ 45$ \\
\hline \multirow[t]{6}{*}{ II } & $\mathrm{N} 21$ & Pyrrbotite & 4.4 & 4.1 & 346 \\
\hline & №3 & Bismethinite & 2.1 & 4.4 & 298 \\
\hline & $\mathrm{i} 24.2$ & Pyrrborite & 4.8 & $4 \ldots$ & 323 \\
\hline & & Chalecrpyrite & 4.7 & 4.8 & 323 \\
\hline & $\sqrt{25}$ & Bisnutainite & $2 \ldots 3$ & 4.7 & 286 \\
\hline & $\mathrm{N} 28-1$ & Pyrrhotite & 4.6 & 4.3 & 319 \\
\hline
\end{tabular}

* Catculated from Ohmono \& Goldhiber (1997). ** Hased on average temperalure of homnogentzation of fluid inclusions in the associated quarti. 
vuggy quartz. Another typical hydrothermal bismuth ore deposit is the Yucheon mine, South Korea, which consists of quartz veins that filled fault-related fractures within Cretaceous sedimentary and Tertiary igneous rocks. That deposit was found to have similar temperatures of main mineralization of bismuth ranging from 250 to $350^{\circ} \mathrm{C}$ at pressure condition about 210 bars (Yun et al. 2001).

To obtain the trapping temperature of type-IB inclusions, a pressure correction needs to be added to their homogenization temperatures, 278 to $385^{\circ} \mathrm{C}$. If we take the maximum pressure (200 bars) from the calculated values above, the temperature correction amounts to only about $10^{\circ} \mathrm{C}$ or more from the pressure-correction diagrams suggested by Potter et al. (1977). Therefore, the trapping temperature of type-IB fluids that were involved in the initial formation of veins at stage II is estimated to be above $400^{\circ} \mathrm{C}$. Although the diagrams used are based on the system $\mathrm{H}_{2} \mathrm{O}-\mathrm{NaCl}$, their applications to type-IB fluids possibly containing other salts, like $\mathrm{Ca}$, $\mathrm{K}$, or $\mathrm{Mg}$ in addition to $\mathrm{Na}$, would cause little variation in the results (Clynne \& Potter 1977). As for stage I, under lithostatic loads, a depth of $2 \mathrm{~km}$ is equivalent to a pressure of 500 bars (Fig. 13), and the corresponding temperature-correction is about 40 to $50^{\circ} \mathrm{C}$ at $20 \mathrm{wt} . \%$ $\mathrm{NaCl}$ solutions (Potter et al. 1977). Therefore, the temperature of trapping of type-I fluids at stage I related to the arsenic mineralization would range from $330^{\circ}$ to $450^{\circ} \mathrm{C}$.

The sulfur fugacity at stage I during the precipitation of the assemblage arsenopyrite - pyrite - sphalerite can be estimated from the sulfidation curve constrained by the temperature of trapping of fluid inclusions obtained from the relevant sample, and by the FeS content of sphalerite; the results are $10^{-9.1}$ to $10^{-6.4}$ bar (Fig. 14). At stage II, during the bismuthinite - native bismuth mineralization, the sulfur fugacity decreased to $10^{-15.7}$ to $10^{-9.2}$ bar. Thus, we conclude that mineralization was initiated with arsenic precipitation at conditions of high fugacity of sulfur, and, with decrease in sulfur fugacity, bismuth mineralization was favored.

\section{Mechanisms of ore mineralization}

The hydrothermal fluids at stage I that were not boiling may have had appreciable dissolved $\mathrm{CO}_{2}$ and $\mathrm{H}_{2} \mathrm{~S}$, as discussed above, thereby enhancing the solubility of metals (such as As, $\mathrm{Zn}, \mathrm{Cu}$ and $\mathrm{Fe}$ ) as sulfide complexes. The metals are transported mainly as chloride complexes like $\mathrm{ZnCl}_{2}, \mathrm{FeCl}_{2}$, and $\mathrm{CuCl}^{0}$ (Seward \& Barnes 1997). These metals could precipitate continuously from high-temperature fluids, according to simplified reaction (3), as a result of $\mathrm{pH}$ increase due to interaction with calcite in wallrocks, the Maggol limestone; the

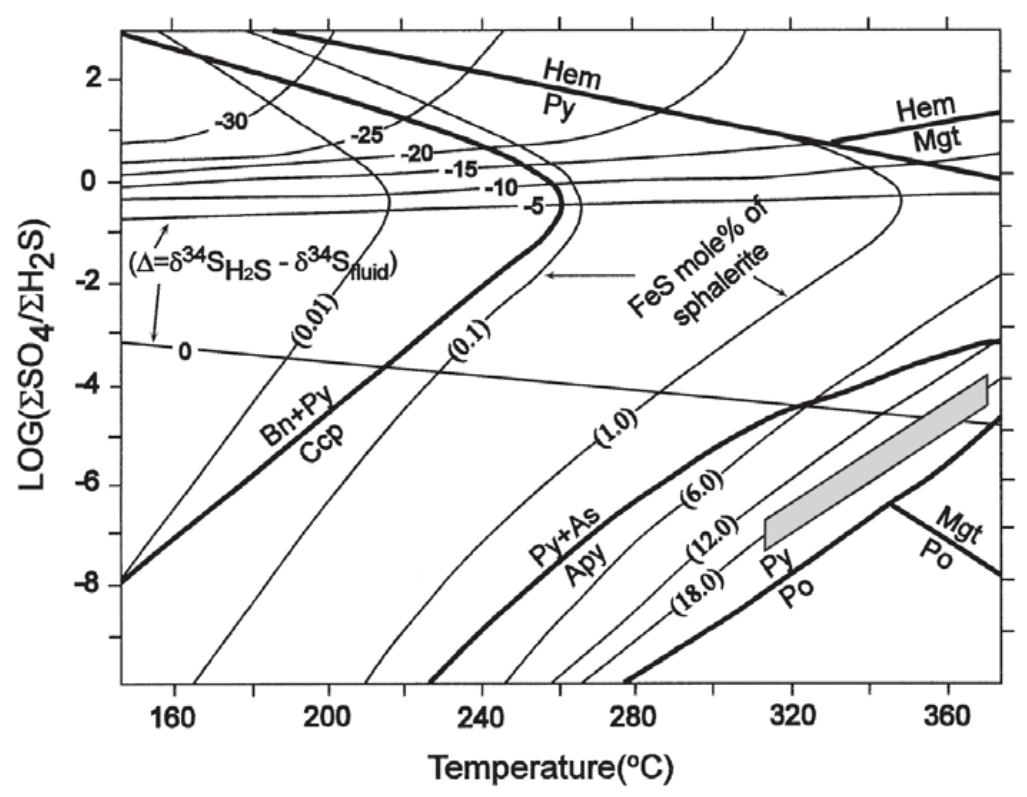

FIG. 11. Diagram showing $\log \left(\Sigma \mathrm{SO}_{4} / \Sigma \mathrm{H}_{2} \mathrm{~S}\right)$ versus temperature. $\mathrm{H}_{2} \mathrm{~S}$ is the dominant sulfur-bearing species in the fluid circulating in the vicinity of the Nakdong deposits (shaded area). The deviation between $\delta^{34} \mathrm{~S}_{\mathrm{H} 2 \mathrm{~S}}$ and $\delta{ }^{34} \mathrm{~S}_{\text {fluid }}$ is very small (Ripley \& Ohmoto 1980, Ohmoto \& Lasaga 1982). Refer to Figure 3 for abbreviations; also, Bn: bornite, Hem: hematite, Mgt: magnetite, As: arsenic). 
solubilities of these metals progressively decreased with increasing $\mathrm{pH}$ and decreasing temperature.

$$
\mathrm{ZnCl}_{2}(\mathrm{aq})+\mathrm{H}_{2} \mathrm{~S}(\mathrm{aq})=\mathrm{ZnS}+2 \mathrm{H}^{+}+2 \mathrm{Cl}^{-}
$$

Aqueous $\mathrm{As}^{3+}$ is dominantly transported as the complex $\mathrm{As}(\mathrm{OH})_{3}(\mathrm{aq})$ in most moderate- to high-temperature and acidic to neutral hydrothermal aqueous fluids (Pokrovski et al. 2002a, b). Arsenic chloride or sulfide complexes like $\mathrm{As}_{2} \mathrm{~S}_{3}(\mathrm{aq}), \mathrm{HAs}_{2} \mathrm{~S}_{4}{ }^{-}$, and $\mathrm{As}_{2} \mathrm{~S}_{4}{ }^{2-}$, however, were found to be negligible in the presence of $\mathrm{HCl}$ or $\mathrm{H}_{2} \mathrm{~S}$ (Pokrovski et al. 2002b). Thus the following reaction can be suggested for the formation of arsenopyrite with increasing $\mathrm{pH}$ and decreasing temperature in the Nakdong deposits:

$$
\begin{aligned}
& \mathrm{FeCl}_{2}(\mathrm{aq})+\mathrm{As}(\mathrm{OH})_{3}(\mathrm{aq})+\mathrm{H}_{2} \mathrm{~S}(\mathrm{aq})+\mathrm{H}_{2}(\mathrm{aq}) \\
& =\mathrm{FeAsS}+3 \mathrm{H}_{2} \mathrm{O}+2 \mathrm{H}^{+}+2 \mathrm{Cl}^{-}
\end{aligned}
$$

Given the widespread association of bismuth with pyrrhotite and chalcopyrite within stage-II veins, the precipitation of sulfides triggered bismuth mineralization through decreasing $f\left(\mathrm{H}_{2} \mathrm{~S}\right)$. In addition, it has been suggested that fluid immiscibility is a common phenomenon in association with base-metal mineralization in a variety of hydrothermal deposits (Bowers 1991, Graupner et al. 1999). Therefore, a decrease of sulfur fugacity through sulfide precipitation and $\mathrm{H}_{2} \mathrm{~S}$ loss, with decreasing solubility of metals, may have induced bismuth precipitation through destabilization of bisulfide complexes.

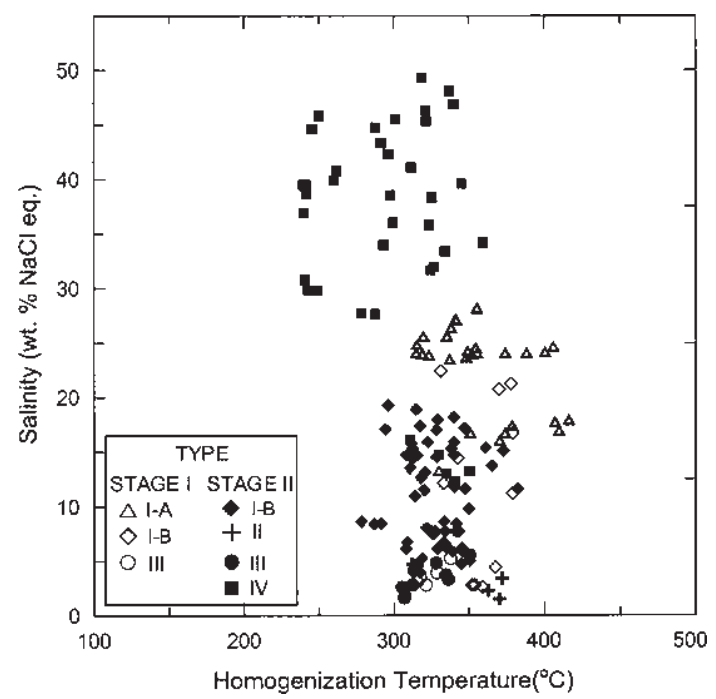

FIG. 12. Plots of temperature of total homogenization versus salinity for fluid inclusions from the Nakdong deposits.
Gold, though present as traces in the Nakdong deposits, is very intimately associated with bismuth along cracks in pyrite (Fig. 3). The liquid-bismuth collector model proposed by Douglas et al. (2000) shows that there is a strong partition of gold into liquid bismuth from a hydrothermal fluid at $300^{\circ} \mathrm{C}$; as much as $20 \mathrm{wt} . \%$ gold may be dissolved into the liquid bismuth. Those elements thus behave in a very compatible mode in a hydrothermal fluid, as advocated by Maloof et al. (2001) and Mustard (2001) in some natural occurrences. It is worth noting here that $\mathrm{AuCl}_{2}{ }^{-}$dominates at high temperature $\left(>290^{\circ} \mathrm{C}\right)$ and high salinity $(>4 \mathrm{wt} . \% \mathrm{NaCl})$, whereas $\mathrm{Au}(\mathrm{HS})_{2}{ }^{-}$is stable at low-temperature and lowsalinity conditions (Large et al. 1988). Generally, the solubility of $\mathrm{Au}$ is higher as $\mathrm{AuCl}_{2}^{-}$, and that of $\mathrm{Ag}$ as $\mathrm{Ag}(\mathrm{HS})_{2}{ }^{-}$; the ratio $\mathrm{AuCl}_{2}{ }^{-} / \mathrm{Ag}(\mathrm{HS})_{2}{ }^{-}$increases with increasing temperature, salinity, and sulfur fugacity (Seward 1991). However, a high salinity of bulk fluids ( 11 wt.\%), but high to low temperatures $\left(395-222^{\circ} \mathrm{C}\right)$ and considerably variable content of gold, as indicated by a $\mathrm{Ag}: \mathrm{Au}$ ratio of 0.47 to 3.58 , imply that both $\mathrm{Au}(\mathrm{HS})_{2}{ }^{-}$and $\mathrm{AuCl}_{2}{ }^{-}$complex ions played an important role in the transport of gold as well as bismuth in the Nakdong deposits. In addition, in many mesothermal and epithermal deposits containing arsenopyrite, gold precipitation occurs later than the formation of arsenopyrite \pm pyrite (e.g., Genkin et al. 1998), as in the Nakdong deposits. As the reverse process of reaction 4 could act as a local redox trap for gold (Pokrovski et al. 2002a), the precipitation of gold as well as bismuth in the Nakdong deposits could be affected by reducing conditions from the local dissolution of arsenopyrite.

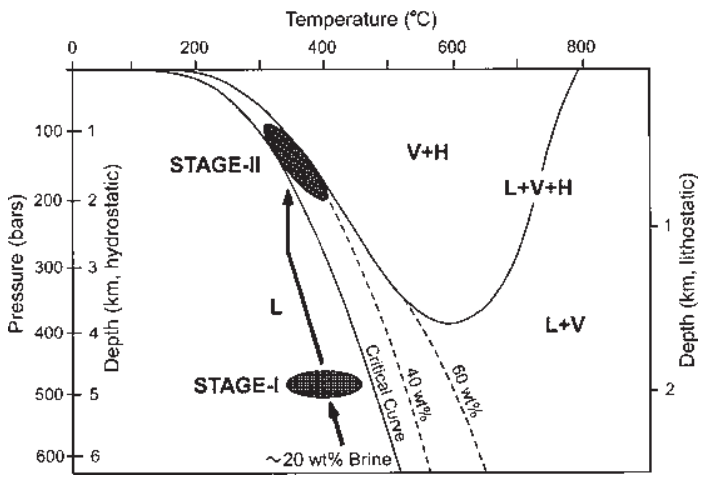

FIG. 13. Pressure-temperature diagram (after Fournier 1987) illustrating conditions of trapping of fluid inclusions. Critical curve for pure $\mathrm{H}_{2} \mathrm{O}, \mathrm{L}$ : liquid, $\mathrm{V}$ : vapor, and $\mathrm{H}$ : halite. Depths assuming a $1 \mathrm{~g} / \mathrm{cm}^{3}$ hydrostatic load and a $2.5 \mathrm{~g} /$ $\mathrm{cm}^{3}$ lithostatic load are also shown. Isopleths of $\mathrm{NaCl}$ in liquid are shown by the dashed lines. With intersection of the solvus, the fluid involved in bismuth mineralization in stage II separated into about $40 \mathrm{wt} \%$ hypersaline fluid of type IV with vapor-rich low-salinity fluid of type II. 


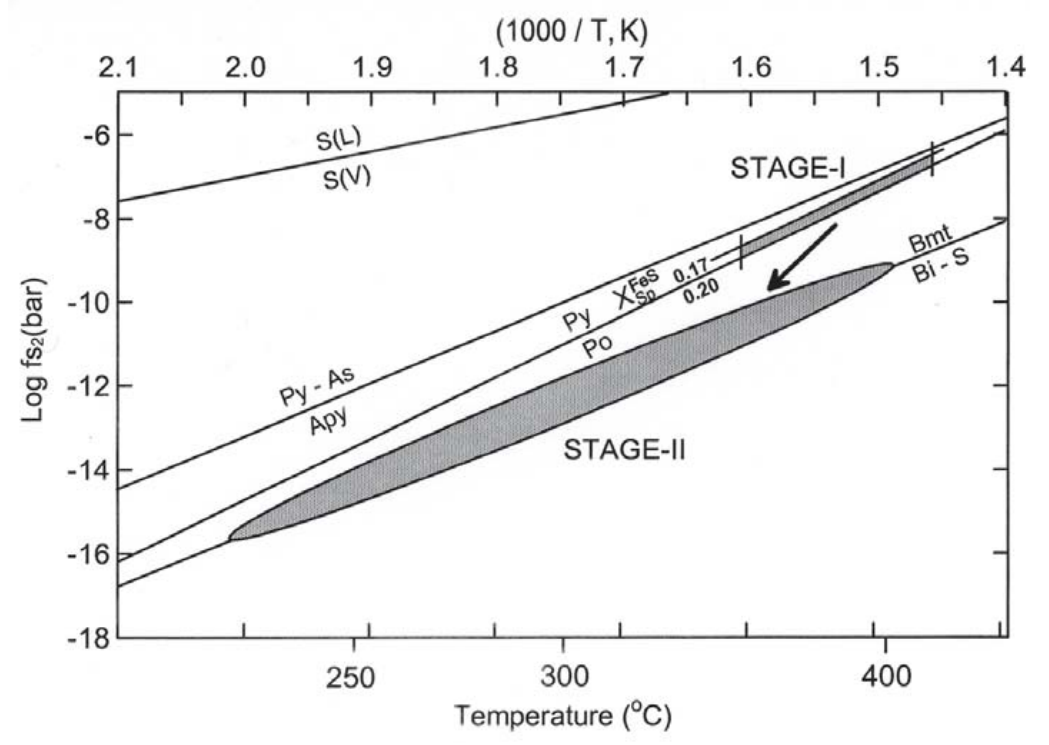

FIG. 14. Diagram showing the possible range of sulfur fugacity and temperature for mineral assemblages of stage I and II at the Nakdong deposits (modified from Barton \& Skinner 1979). Temperature data are given by fluid inclusions. Refer to Figure 3 and 11 for abbreviations; also Sp: sphalerite, S: sulfur).

\section{ACKNOWLEDGEMENTS}

This work was supported by Korea Research Foundation Grant (KRF-2000-015-DP0439). We acknowledge the graduate fellowship provided by the BK 21 Project of the Korean Government. We are grateful to Dr. Sundo Hur at Korea Ocean Research \& Development Institute for his valuable discussions and suggestions, both in the field and in the laboratory. Critical reviews by D.J. Kontak, R.F. Martin and K.L. Shelton substantially improved this contribution and are greatly appreciated.

\section{REFERENCES}

Barton, P.B. \& Skinner, B.J. (1979): Sulfide mineral stabilities. In Geochemistry of Hydrothermal Ore Deposits (H.L. Barnes, ed.; $2^{\text {nd }}$ edition). John Wiley \& Sons, New York, N.Y. (278-403).

Bottrell, S.H., Shepherd, T.J., Yardley, B.W.D. \& DuBESSY, J. (1988): A fluid inclusion model for the genesis of the ore of the Dolyellau gold belt, North Wales. J. Geol. Soc. 145, 139-145.

Bowers, T.S. (1991): The deposition of gold and other metals: pressure-induced fluid immiscibility and associated stable isotope signatures. Geochim. Cosmochim. Acta 55, 24172434.
Bowman, J.R., O'Neil, J.R. \& Essene, E.J. (1985): Contact skarn formation at Elkhorn, Montana. II. Origin and evolution of C-O-H skarn fluids. Am. J. Sci. 285, 621-660.

BuRNHAM, C.W. (1997): Magmas and hydrothermal fluids. In Geochemistry of Hydrothermal Ore Deposits (H.L. Barnes, ed., 3rd edition). John Wiley \& Sons, New York, N.Y. (63123).

BURRUSS, R.C. (1981): Analysis of phase equilibria in C-O$\mathrm{H}-\mathrm{S}$ fluid inclusions. In Fluid Inclusions: Applications to Petrology (L.S. Hollister \& M.L. Crawford, eds.) Mineral. Assoc. Can., Short Course Handbook 6, 39-74.

Chacko, T., Mayeda, T.K., Clayton, R.N. \& Goldsmith, J.R. (1991): Oxygen and carbon isotope fractionations between $\mathrm{CO}_{2}$ and calcite. Geochim. Cosmochim. Acta $\mathbf{5 5}$, 2867-2882.

Clayton, R.N. \& MAYeda, T.K. (1963): The use of bromine pentafluoride in the extraction of oxygen from oxides and silicates for isotopic analysis. Geochim. Cosmochim. Acta 27, 43-52.

Cluzel, D., CAdet, J.P. \& LaPierre, H. (1990): Geodynamics of the Ogcheon Belt (South Korea). Tectonophysics 183, 41-56.

Clynne, M.A. \& PotTer, R.W., II (1977): Freezing point depression of synthetic brines. Geol. Soc. Am., Abstr. Programs $\mathbf{9 ,} 930$. 
ColLins, P.L.F. (1979): Gas hydrates in $\mathrm{CO}_{2}$-bearing inclusions and the use of freezing data for estimation of salinity. Econ. Geol. 74, 1435-1444.

CoOK, S.J., Bowman, J.R. \& Forster, C.B. (1997): Contact metamorphism surrounding the Alta stock: finite element model simulation of heat- and ${ }^{18} \mathrm{O} /{ }^{16} \mathrm{O}$ mass-transport during prograde metamorphism. Am. J. Sci. 297, 1-55.

Crawford, M.L. (1981): Phase equilibria in aqueous fluid inclusions. In Fluid Inclusions: Applications to Petrology (L.S. Hollister \& M.L. Crawford, eds.). Mineral. Assoc. Can., Short Course Handbook 6, 75-100.

DARLING, R.S. (1991): An extended equation to calculate $\mathrm{NaCl}$ contents from final clathrate melting temperatures in $\mathrm{H}_{2} \mathrm{O}-$ $\mathrm{CO}_{2}-\mathrm{NaCl}$ fluid inclusions: implications for $\mathrm{P}-\mathrm{T}$ isochore location. Geochim. Cosmochim. Acta 55, 3869-3871.

DAVIS, D.W., LowensteIn, T.K. \& SPENCER, R.J. (1990): Melting behavior of fluid inclusions in laboratory-grown halite crystals in the systems $\mathrm{NaCl}-\mathrm{H}_{2} \mathrm{O}, \mathrm{NaCl}-\mathrm{KCl}-\mathrm{H}_{2} \mathrm{O}, \mathrm{NaCl}-$ $\mathrm{MgCl}_{2}-\mathrm{H}_{2} \mathrm{O}$, and $\mathrm{NaCl}-\mathrm{CaCl}_{2}-\mathrm{H}_{2} \mathrm{O}$. Geochim. Cosmochim. Acta 54, 591-601.

Douglas, N., Mavrogenes, J., Hack, A. \& England, R. (2000): The liquid bismuth collector model: an alternative gold deposition mechanism. Geol. Soc. Aust., Abstr. 59, 135.

FouRNIER, R.O. (1987): Conceptual models of brine evolution in magmatic-hydrothermal systems. U.S. Geol. Surv., Prof. Pap. 1350, 1487-1506.

Genkin, A.D., Bortnikov, N.S., CABRI, L.J., WAGNer, F.E., Stanley, C.J., Safonov, Y.G., McMahon, G., Friedl, J., Kerzin, A.L. \& Gamyanin, G.N. (1998): A multidisciplinary study of invisible gold in arsenopyrite from four mesothermal gold deposits in Siberia, Russian Federation. Econ. Geol. 93, 463-487.

Graupner, T., Kempe, U., Dombon, E., Pätzold, O., Leeder, O. \& SPOONER, E.T.C. (1999): Fluid regime and ore formation in the tungsten(-yttrium) deposits of Kyzyltau (Mongolian Altai): evidence for fluid variability in tungsten-tin ore systems. Chem. Geol. 154, 21-58.

HANOR, J.S. (1994): Origin of saline fluids in sedimentary basins. In Geofluids: Origin, Migration and Evolution of Fluids in Sedimentary Basins (J. Parnell, ed.). Geol. Soc. London, Spec. Publ. 78, 151-174.

Higgins, N.C. (1980): Fluid inclusion evidence for the transport of tungsten by carbonate complexes in hydrothermal solution. Can. J. Earth Sci. 17, 823-830.

HuR, S.D. (1997): Petrochemistry of the Jeongseon Granitoids and Genesis of Associated Pb, Zn, Cu Deposits. Ph.D. thesis, Seoul National Univ., Seoul, Korea.

\& PARK, H.I. (2000): Ore mineralogy and fluid inclusion study on the Shinjeongseon $\mathrm{Pb}-\mathrm{Zn}$ ore deposit, Jeongseon, Korea. J. Geol. Soc. Korea 36, 93-112.
, LeE, I.S., Hwang, J. \& LeE, C.H. (2000):

Metallogeny of the northern part of Taebaegsan area, Korea. Geosciences J. 4, 172-175.

JeONG, U.J. (1995): Geological Structures and Deformational Sequences of Jeongseon Area, Kangweon-do, Korea. M.S. thesis, Seoul National University, Seoul, Korea.

KeIth, M.L. \& Weber, J.N. (1964): Carbon and oxygen isotopic composition of selected limestone and fossils. Geochim. Cosmochim. Acta 28, 1787-1816.

Kim, K.H., Kim, O.J., NAKaI, N. \& LeE, H.J. (1988): Stable isotope studies of the Sangdong tungsten ore deposits, South Korea. Mining Geol. 38, 473-487.

\& NAKAI, N. (1982): Sulfur isotope composition and isotopic temperatures of the Shinyemi lead and zinc ore deposit, western Taebaegsan metallogenic belt, Korea. $J$. Korean Inst. Mining Geol. 15, 155-166.

KMPC (KoRea Mining Promotion CoRporation) (1974): Ore Deposits of Korea 6, 89-90.

Large, R.R., Huston, D.L., McGoldrick, P.J., Ruxton, P.A \& MCARTHUR, G. (1988): Gold distribution and genesis in Australian volcanogenic massive sulfide deposits and their significance for gold transport model. Econ. Geol., Monogr. 6, 520-536.

LeE, HA Young (1979): A study on biostratigraphy and bioprovince of the middle Orodovician conodonts from South Korea. J. Geol. Soc. Korea 15, 37-60.

Li, Chusi \& NALDReTt, A.J. (1993): High chlorine alteration minerals and calcium-rich brines in fluid inclusions from the Strathcona deep copper zone, Sudbury, Ontario. Econ. Geol. 88, 1780-1796.

Maloof, T.L., Baker, T. \& Thompson, J.F.H. (2001): The Dublin Gulch intrusion-hosted gold deposit, Tombstone plutonic suite, Yukon Territory, Canada. Mineral. Deposita 36, 583-593.

Mattey, D.P., TAylor, W.R., Green, D.H. \& Pillinger, C.T. (1990): Carbon isotopic fractionation between $\mathrm{CO}_{2}$ vapor, silicate melt and carbonate melts: an experimental study to 30 kbar. Contrib. Mineral. Petrol. 104, 492-505.

MustaRD, R. (2001): Granite-hosted gold mineralization at Timbarra, northern New South Wales, Australia. Mineral. Deposita 36, 542-562.

OAKES, C.S., BODNAR, R.J. \& SimONSON, J.M. (1990): The system $\mathrm{NaCl}-\mathrm{CaCl}_{2}-\mathrm{H}_{2} \mathrm{O}$. I. The ice liquidus at $1 \mathrm{~atm}$ total pressure. Geochim. Cosmochim. Acta 54, 603-610.

Онмото, H. \& Goldhaber, M.B. (1997): Sulfur and carbon isotopes. In Geochemistry of Hydrothermal Ore Deposits (H.L. Barnes, ed.; 3rd edition). John Wiley \& Sons, New York, N.Y. (517-611).

\& LASAGA, A.C. (1982): Kinetics of reactions between aqueous sulfates and sulfides in hydrothermal systems. Geochim. Cosmochim. Acta 46, 1727-1745. 
PARK, H.I., Chang, H.W. \& Jin, M.S. (1988): K-Ar ages of mineral deposits in the Taebaeg Mountain district. J. Korean Inst. Mining Geol. 21, 57-67.

\& LEE, C.H. (1990): The Au-Ag mineralization of North Ore Deposits, Dunjeon gold mine. J. Geol. Soc. Korea 26, 358-370.

Pokrovski, G., Kara, S. \& Roux, J. (2002a): Stability and solubility of arsenopyrite, FeAsS, in crustal fluids. Geochim. Cosmochim. Acta 66, 2361-2378.

Zakirov, I., Roux, J. Testemale, D., Hazemann, J-L., BychKov, A.Y. \& Golikova, G.V. (2002b): Experimental study of arsenic speciation in vapor phase to $500^{\circ} \mathrm{C}$ : implications for As transport and fractionation in low-density crustal fluids and volcanic gases. Geochim. Cosmochim. Acta 66, 3453-3480.

Potter, R.W., II, BAвсоск, R.S. \& Brown, D.L. (1977): A new method for determining the solubility of salts in aqueous solutions at elevated temperatures. J. Res. U.S. Geol. Surv. 5, 389-395.

Clynne, M.A. \& Brown, D.L. (1978): Freezing point depression of aqueous sodium chloride solutions. Econ. Geol. 73, 284-285.

RIPLEY, E.M. \& Oнмото, H. (1980): A FORTRAN program for plotting mineral stabilities in the $\mathrm{Fe}-\mathrm{Cu}-\mathrm{S}-\mathrm{O}$ system in terms of $\log \left(\Sigma \mathrm{SO}_{4} / \Sigma \mathrm{H}_{2} \mathrm{~S}\right)$ or $\log$ fo $_{2}$ vs. pH or T. Comput. Geosci. 5, 289-300.

Roedder, E. (1984): Fluid Inclusions. Rev. Mineral. 12.

SEWARD, T.M. (1991): The hydrothermal geochemistry of gold. In Gold Metallogeny and Exploration (R.P. Foster, R.P., ed.). Blackies, Glasgow, U.K. (165-209).

\& BARNES, H.L. (1997): Metal transport by hydrothermal ore fluids. In Geochemistry of Hydrothermal Ore Deposits (H.L. Barnes, ed.; 3rd edition). John Wiley \& Sons, New York, N.Y. (435-486).

Shelton, K.L., So, ChIL-Sup \& Chang, Jin-Su (1988): Goldrich mesothermal vein deposits of the Republic of Korea: geochemical studies of the Jungwon gold area. Econ. Geol. 83, 1221-1237.

Haeussler, G.T., Chi, Se-Jung \& LeE, KYEONG-YONG (1990): Geochemical studies of the
Tongyoung gold-silver deposits, Republic of Korea: evidence of meteoric water dominance in a Te-bearing epithermal system. Econ. Geol. 85, 1114-1132.

Sterner, S.M., Hall, D.L. \& Bodnar, R.J. (1988): Synthetic fluid inclusions. V. Solubility relations in the system $\mathrm{NaCl}-$ $\mathrm{KCl}-\mathrm{H}_{2} \mathrm{O}$ under vapor-saturated conditions. Geochim. Cosmochim. Acta 52, 989-1005.

TAYLOR, B.E. (1986): Magmatic volatiles: isotopic variation of $\mathrm{C}, \mathrm{H}$, and S. In Stable Isotopes in High Temperature Geological Processes (J.W. Valley, H.P. Taylor, Jr. \& J.R. O’Neil, eds.). Rev. Mineral. 16, 185-225.

TAYLOR, H.P., JR. \& SHEPPARD, S.M.F. (1986): Igneous rocks. I. Processes of isotopic fractionation and isotope systematics. In Stable Isotopes in High Temperature Geological Processes (J.W. Valley, H.P. Taylor, Jr. \& J.R. O’Neil, eds.). Rev. Mineral. 16, 227-271.

Valenza, K., Moritz, R., Mouttaqi, A., Fontignie, D. \& Sharp, Z. (2000): Vein and karst barite deposits in the Western Jebilet of Morocco: fluid inclusion and isotope ( $S$, $\mathrm{O}, \mathrm{Sr}$ ) evidence for regional fluid mixing related to Central Atlantic Rifting. Econ. Geol. 95, 587-606.

VALLEY, J.W. (1986): Stable isotope geochemistry of metamorphic rocks. In Stable Isotopes in High Temperature Geological Processes (J.W. Valley, H.P. Taylor, Jr. \& J.R. O’Neil, eds.). Rev. Mineral. 16, 445-489.

Yun, SeOng-Taek, So, Chil-Sup, Choi, Sang-Hoon \& HeO, CHul-Ho (2001): Hydrothermal bismuth mineralization at the Yucheon mine, South Korea: oxygen and hydrogen isotope study. Geosciences J. 5, 243-250.

Zhang, Yi GANG \& FRANTZ, J.D. (1987): Determination of the homogenization temperatures and densities of supercritical fluids in the system $\mathrm{NaCl}-\mathrm{KCl}-\mathrm{CaCl}_{2}-\mathrm{H}_{2} \mathrm{O}$ using synthetic fluid inclusions. Chem. Geol. 64, 335-350.

ZHENG, Yong-FeI (1993): Calculation of oxygen isotope fractionation in anhydrous silicate minerals. Geochim. Cosmochim. Acta 57, 1079-1091.

(1999): Oxygen isotope fractionation in carbonate and sulfate minerals. Geochem. J. 33, 109-126.

Received January 22, 2003, revised manuscript accepted December 31, 2003. 